\section{The Naturalist's Journals of Gilbert White: exploring the roots of accounting for biodiversity and extinction accounting}

\section{Roots of accounting for biodiversity}

Jill Atkins

Sheffield University Management School, The University of Sheffield, Sheffield, UK, and

Warren Maroun

School of Accountancy, University of the Witwatersrand, Johannesburg, South Africa
Received 12 March 2016 Revised 17 January 2019 17 January 2020 12 March 2020

Accepted 17 March 2020

\begin{abstract}
Purpose - This paper explores the historical roots of accounting for biodiversity and extinction accounting by analysing the 18th-century Naturalist's Journals of Gilbert White and interpreting them as biodiversity accounts produced by an interested party. The authors aim to contribute to the accounting history literature by extending the form of accounting studied to include nature diaries as well as by exploring historical ecological accounts, as well as contributing to the burgeoning literature on accounting for biodiversity and extinction accounting.

Design/methodology/approach - The authors' method involves analysing the content of Gilbert White's Naturalist's Journals by producing an 18th-century biodiversity account of species of flora and fauna and then interpretively drawing out themes from the Journals. The authors then provide a Whitean extinction account by comparing current species' status with White's biodiversity account from 250 years ago.

Findings - This paper uses Gilbert White's Naturalist's Journals as a basis for comparing biodiversity and natural capital 250 years ago with current species' status according to extinction threat and conservation status. Further the paper shows how early nature diary recording represents early (and probably the only) forms of accounting for biodiversity and extinction. The authors also highlight themes within White's accounts
\end{abstract}

(C) Jill Atkins and Warren Maroun. Published by Emerald Group Publishing Limited. This article is published under the Creative Commons Attribution (CC BY 4.0) licence. Anyone may reproduce, distribute, translate and create derivative works of this article (for both commercial and non-commercial purposes), subject to full attribution to the original publication and authors. The full terms of this licence may be seen at http://creativecommons.org/licences/by/4.0/legalcode

The authors are grateful to a number of people who have commented on drafts of this paper, especially Barry Atkins, Simon Norton and Steve Walker. The authors would also like to thank Richard Laughlin for his insights and guidance on developing the paper. They are grateful to delegates at the British Accounting Association conference in Cardiff, April 2010, for their suggestions, especially Jane Broadbent, Sonja Gallhofer, Doris Merkyl-Davis. Thanks also to delegates at the CSEAR Summer School, St Andrews, September 2010, for their comments, Rob Gray, Chris Kensall, John Margerison. The authors would also like to thank Christopher Napier for his comments and suggestions on the development of this paper and Mike Jones for his suggestions in relation to accounting history and biodiversity accounting. They are grateful to attendees at a staff seminar presentation of this paper at the University of Pisa, Italy, in December 2018, especially to Federica Doni and Antonello Corvino, for their comments, as well as to colleagues who attended a staff seminar presentation of the paper at the University of Gothenburg, Sweden, in December 2018, especially Gunnar Rimmell and Kristina Jonäll. Thanks also to the anonymous reviewers who have made constructive comments and suggestions that have resulted in a far richer and more insightful paper. The authors would especially like to pay their respects to the late Jack Christian, who had always been a wonderful inspiration and who was so helpful and supportive in developing this and other papers. Lastly, Jill would like to remember her late parents, Brenda Ann and Derek Thompson, for the constant love and support they gave her whilst writing this paper, their interest in this work on Gilbert White and in everything she has done.

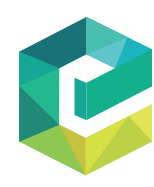

Accounting, Auditing \& Accountability Journal Vol. 33 No. 8, 2020 pp. $1835-1870$

Emerald Publishing Limited DOI 10.1108/AAAJ-03-2016-2450 
AAAJ 33,8

1836

including social emancipation, problematisation, aesthetic elements and an example of an early audit of biodiversity accounting.

Research limitations/implications - There are limitations to analysing Gilbert White's Naturalist's Journals given that the only available source is an edited version. The authors therefore interpret their data as accounts which are indicative of biodiversity and species abundance rather than an exactly accurate account.

Practical implications - From the authors' analysis and reflections, the authors suggest that contemporary biodiversity accounting needs to incorporate a combination of narrative, data accounting and pictorial/ aesthetic representation if it is to provide a rich and accurate report of biodiversity and nature. The authors also suggest that extinction accounting should draw on historical data in order to demonstrate change in natural capital over time.

Social implications - Social implications include the understanding gleaned from the authors' analysis of the role of Gilbert White as a nature diarist in society and the contribution made over time by his Journals and other writings to the development of nature accounting and recording, as well as to one's understanding and knowledge of species of flora and fauna.

Originality/value - To the authors' knowledge this is the first attempt to analyse and interpret nature diaries as accounts of biodiversity and extinction.

Keywords Species, Biodiversity accounting, Extinction accounting, Emancipatory, Gilbert White, Naturalist's Journals

Paper type Research paper

\section{Introduction}

Increasing interest in accounting for sustainability in recent years has been accompanied, to some extent, by historical research into social and environmental accounting with researchers exploring

... how earlier individuals and organisations used accounting to enable, or in some cases ignore, sustainability, and to hold the powerful accountable for their impact on nature (Carnegie and Napier, 2017, p. 85).

Nevertheless, the body of historical social and environmental accounting research remains relatively small, and there have been calls for further exploration of environmental accounting in a historical context (Parker, 2015; Carnegie and Napier, 2017). One avenue taken by accounting history researchers is to adopt a biographical approach, as it is not possible to understand contemporary accounting without examining the key personalities who have contributed to the development of that accounting (Carnegie and Napier, 2017). Indeed, accounting history research has explored a biographical, as well as a prosopographical, approach to researching the role of those providing accounts in a historical context [1]. This paper adopts a biographical research approach in examining Gilbert White, exploring his life, character, surroundings, cultural context and focussing on White's Naturalist's Journals [2] as early illustrations of accounting for biodiversity. These Journals, in our view, represent the roots of accounting for biodiversity. In terms of method, we seek to combine the biographical method applied in accounting history research with a thematic content analysis frequently used in social and environmental accounting research. Specifically, this paper examines the Naturalist's Journals of Gilbert White in the context of his life, his work and the time in which he lived. Specifically, we explore the commonalities between White's Journals as accounts of species, both flora and fauna, and accounting in the more traditional, financial sense. White kept detailed financial accounts throughout his life. We consider how this recording activity paved the way for his later Naturalist's Journals as 18th-century accounts of biodiversity. Therefore, our research contributes to, and extends, existing research in environmental accounting by extending the form of account under study whilst at the same time exploring the historical roots of environmental accounting. More historical research in environmental accounting and the exploration of different forms of accounting have both been called for in the recent accounting literature by Parker (2015) in terms of historical perspectives on social and environmental accounting research and in terms of form, as follows: 
Opportunities to broaden an awareness of the tentacles of accounting and forms of accountability in everyday life settings reside in both private and public archives located around the globe (Carnegie and Napier, 2017, p. 85).

White's Naturalist's Journals seem to represent an important "tentacle" stretching towards us from a quarter of a millennium ago and forming the roots of contemporary accounts of biodiversity and species. The narrow and parochial nature of the modern use of accounting has been subject to increasing criticism (Burchell et al., 1980; Carnegie and Napier, 1996; Gallhofer et al., 2015). Carnegie and Napier (1996), for instance, emphasise that there is a need to widen the notion of the "archive" beyond the traditional "obviously accounting-based source materials" (p. 31) such as original accounts, business records and financial statements (see also Napier, 2006). We argue that broadening the definition of "archival evidence" (and the functioning of accounting systems) extends to external data sources dealing with environmental change to reveal, in more detail, exactly how contemporary (and diverse) forms of accounting function (Burchell et al., 1980, p. 23).

Alternate forms of environmental accounting produced by stakeholders, rather than business organisations, have been largely neglected by mainstream accounting researchers (Solomon and Thomson, 2009). This is despite the fact that recordings of environmental metrics by interested parties external to business organisations (and dating to the $1700 \mathrm{~s}$, 1800s and modern times) provide important accounts of environmental information and the impact of human and business activity on the natural world (Lewis et al., 1984; Guthrie and Parker, 1989; Unerman, 2003; Maltby, 2004; Solomon and Thomson, 2009). As a result, this external reporting perspective is the locus of this paper, which presents White's Naturalist's Journals as a form of accounting for biodiversity, and more specifically for species of flora and fauna, consistent with the growing literature on accounting for extinction. We see White's Naturalist's Journals, and indeed nature diaries more generally, as a strand of the roots of contemporary biodiversity reporting. Nature diaries, at a fundamental level, are vehicles for data collection, recording and cataloguing species. Like financial accounting, they represent a

... taken for granted, somewhat unexciting and unappealing mechanical practice that records and reports the "facts" that are simply to be recorded and reported, a technical practice that almost just is (Gallhofer and Haslam, 2003, p. 1).

On closer inspection, however, nature diaries represent collections of data, in narrative form and sometimes in pictorial form, that can document nature and mankind's accountability and stewardship for it. A record of nature by an interested observer has been described as

... sending, in a faltering new language, a message in a bottle from a disappearing country (Mabey, 2011, p. 13).

This quotation is especially poignant when we compare White's Naturalist's Journals to current assessments of the state of nature provided by scientists. The WWF's recent "Living Planet Report" demonstrates a cavernous divide between wildlife now and species populations around 40 years ago, documenting a $60 \%$ decline in the population size of mammals, birds, fish, reptiles and amphibians (WWF, 2018). The latest scientific assessments show critically significant collapses in species populations in localised ecosystems. For example, arthropod [3] abundance has fallen between 10 and 60 times in a Puerto Rican rainforest over the last 50 years (Lister and Garcia, 2018). For a nature-protected area of Germany, another recent study found a seasonal decline of $76 \%$ in flying insect biomass over the last 27 years. The cascading effects of significant insect loss on ecosystems is well documented, due to their critical role in the survival of flora and fauna [4].

White's writings are interpreted as early illustrations of "Chaos Ecology", as he recognised the way in which fragile natural systems could be completely thrown out of balance by

\section{Roots of accounting for biodiversity}

1837 
AAAJ 33,8

1838

sudden variations in weather patterns or other factors (Scott, 2011). This paper uses White's accounts of species as a comparator with current trends in wildlife populations. A study of British nature diaries more generally identifies them as a literary genre in their own right, a form of "cultural dialogue", which not only records the changing state of the natural world but also has the potential to encourage biodiversity conservation (Bellanca, 2007). In this way, although nature diaries have not previously been interpreted as formal environmental, or biodiversity "accounts", Carnegie and Napier (1996, p. 46) suggest that the use of diaries, as well as other sources, represents an extension of traditional accounting and accountability research. This paper's interpretative analysis of White's Journals as a form of biodiversity accounting conforms with calls from the academic literature for

... new visions of accounting, translating into new practices of accounting, [throwing] off the constraints of past accountings in terms of their content, form, aura and usage (Gallhofer and Haslam, 2003, p. 7).

In this paper, we explore several elements of White's Naturalist's Journals as early accounts of biodiversity, recorded by a passionate observer of nature. Our initial, exploratory analysis of his "accounts" involves considering the species he recorded, in detail, in order to provide a series of tables that represent biodiversity in the area he lived at his time of writing. This gives readers a "snapshot" of biodiversity, as well as of abundance of species, and acts as a basis for further discussion of how a biodiversity account should look, as well as of how we may compare abundance then to abundance now. We then proceed with four further research objectives. First, we consider whether White was in any way "called to account", in other words encouraged to write the journals. Second, we consider his motivation(s) for writing the Naturalist's Journals. Third, we explore other elements and characteristics of these accounts of flora and fauna, such as numerical/quantitative elements, the accuracy of the accounting, emancipatory elements and aesthetic elements. Lastly, we consider for whom the journals were produced, or in accounting terms, who the intended readership was. As well as analysing the accounts, this paper examines White from a biographical perspective in order to understand the person who was providing the account (Carnegie and Napier, 2017), the importance of the accountant himself in order to establish the context, both historical and personal, from which the accounts derived.

The remainder of this paper falls into the following sections. Section 2 reviews existing literature, which explores the roots of environmental accounting from a historical perspective, moving on to discussing the growing literature in accounting for biodiversity and the recent emergence of extinction accounting. In Section 3, we consider the history and development of nature diaries, focussing on Gilbert White and his Naturalist's Journals, as well as reflecting on the ways in which his Journals are similar to financial accounts. We draw on the substantial interdisciplinary literature analysing White's work including studies of his bookkeeping practices as well as his scientific recording of nature and species. Section 4 outlines our research methods. Section 5 presents an analysis of White's Naturalist's Journals as early biodiversity accounts and explores a number of themes arising from the analysis of these accounts. In Section 6, we use the biodiversity accounts constructed from White's Journals as a basis for creating an extinction account of the species he recorded, showing the current conservation status of the species compared with his accounts from 250 years ago. The paper concludes with a discussion and suggestion for future research avenues in this emerging area in Section 7.

\section{The evolution of accounting, accounting for biodiversity and extinction accounting}

2.1 The historical roots of accounting: "naming and counting"

There is a well-established body of academic accounting literature that interprets accounting as an agent of organisational and institutional change rather than merely a neutral 
information processing system (Hopwood, 1987). The "archaeology" of this change potential has been traced to ancient record keeping where social, linguistic and mathematical developments go hand in hand with the emergence of accounting as a technology of accountability (Hoskin and Macve, 1988; Macve, 2015). In Ancient Egypt, for instance, accounting took the form of preparing (in a visible format) a record of items and activities used to coordinate and monitor the efforts of labourers (Ezzamel and Hoskin, 2002). This transactional approach to record keeping - which can also be seen in early double-entry accounting - recorded economic events according to receipts and payouts. A comparable system was employed in Mesopotamia where counters of different shapes modelled in clay were used to record and represent the quantity grains and livestock (Schmandt-Basserat, 1988; Maltessich, 1988, p. 3). In these later Mesopotamian periods, as many as 60 different symbols were employed to track changes in agricultural produce reflecting the development of more sophisticated record-keeping techniques (Maltessich, 1988). Nevertheless, as Ezzamel and Hoskin (2002, p. 335) see it, "any account", irrespective of its specific attributes ultimately, "involves a particular kind of signs which both name and count the items and ... record". This system of "recording [of] transactions via numerical linguistic and money signs", (Ezzamel and Hoskin, 2002, p. 334, emphasis added) is not only about the maintenance of arithmetic accounts but also involves the establishment of a system of control and accountability (Burchell $\mathrm{et}$ al., 1980; Hoskin and Macve, 1988; Hopwood, 1987). We see similarities in these early roots of financial accounting with the environmental reporting context, particularly in relation to accounting for biodiversity, as employed by a nature diarist, as this form of recording and accounting involves observing, identifying, naming and counting, thereby resonating with early forms of accounting. It is the concept of recording that "names and counts", in the earliest forms of financial accounting, which resonates with the early forms of accounting for biodiversity found in White's Naturalist's Journals, whereby he names species, several previously undiscovered, and comments on their abundance and other features or characteristics that he finds notable.

\subsection{Exploring the roots of environmental reporting}

There is a relatively small body of existing literature exploring the historical roots of environmental reporting, especially early "forms" of environmental accounting, often produced by non-accountants. One example is the analysis of a scientific report from the 19 th century as an early form of external environmental report produced by an interested party (Solomon and Thomson, 2009). This report was interpreted as an external account that drew attention to the problem of environmental pollution of the River Wandle. Although the "account" did not in itself constitute a direct call for action, by reporting on specific pollutants and naming and shaming of commercial sites and people responsible, it provided a basis for others to recognise serious problems requiring urgent attention [5]. Further, Atkins and Thomson's (2014) analysis of letters and other writings of William Morris in 19th-century Britain has been described as one of the only attempts to investigate early accounts from a sustainability perspective (Carnegie and Napier, 2017). Another paper analysed the one work of William Morris as a historical source for understanding the development of environmental accounting, by exploring the potential power of the utopian literary genre as a means of critiquing current environmental practices, articulating environmental challenges and providing insights into a theoretical accounting framework capable of contributing to a sustainable future (Solomon and Thomson, 2009; Atkins et al., 2015). Similarly, a recent examination of alternative "accounts" has evaluated the potential for shadow accounts to act as emancipatory, dialogic alternative versions of accounting reality. This is achieved by raising awareness of environmental issues, providing an account of environmental performance external to the company responsible for environmental damage and serving 
AAAJ 33,8

1840

as a basis for stakeholders to hold the organisation responsible for its impact on nature (Solomon and Thomson, 2009; Thomson et al., 2015).

\subsection{From accounting for biodiversity to extinction accounting}

A growing body of work on biodiversity reporting represents the "change potential" of accounting in an environmental reporting context. Jones (1996) develops an inventory approach to accounting for biodiversity which is essentially a form of natural asset accounting. The former, however, specifically focusses on flora and natural habitat and proposes a biodiversity model that records different species in a multi-layered approach to reporting (Jones, 1996). In a later study, Jones (2003) applies his method to a large-scale operation finding that the costs of reporting are modest and that an environmental inventory report "shows the importance of critical habitats in terms of number of species contained". Similar to arguments in a traditional financial reporting system, the proposed biodiversity accounting makes it easier for stakeholders to hold the reporting entity accountable for environmental loss (Jones, 2003, p. 781). Several studies advocate more detailed biodiversity reporting and disclosure frameworks to create awareness of the extent of biodiversity loss, articulate the associated risks, promote accountability and inform the development of monitoring and control of natural capital by the relevant stakeholders (Jones and Solomon, 2013; Rimmel and Jonäll, 2013; Van Liempd and Busch, 2013). Nature diaries may be viewed as an important part of this more comprehensive approach to biodiversity reporting.

Recent papers include frameworks for reporting on biodiversity at the ecological level rather than by individual firms (Cuckston, 2017) complemented by the use of "naturesignalling numbers" which highlight the interconnection among species and their intrinsic value (Cuckston, 2018; Russell et al., 2017; Sullivan and Hannis, 2017). A relatively new development is extinction accounting, whereby organisations are encouraged to report on specific species, the impacts they are having on these species and their habitats and what measures they are taking to reduce these impacts and improve habitats (Atkins and Maroun, 2018; Atkins and Atkins, 2019). Extinction accounting frameworks contain potentially emancipatory elements in that extinction accounting "should" lead to extinction prevention (Maroun and Atkins, 2018). Accounting for biodiversity, unless emancipatory in nature, could simply lead to a "fossil record", whereby species are counted, recorded, reported but allowed to die out (Atkins and Maroun, 2018; Atkins and Atkins, 2019). There is an emerging body of work on extinction accounting in the context of specific species, such as panda (Zhao and Atkins, 2019), polar bear (Jonäll and Sabelfeld, 2019), monarch butterflies (Lanka, 2019) and rhinoceros (Atkins et al., 2018). There is also research into extinction accounting in the public sector and national parks (Weir, 2018; Buchling and Maroun, 2019; Sibanda and Mulama, 2019), zoos (Rimmel, 2019) and aquaria (Solomon and Clappison, 2019). This paper intends to contribute to the burgeoning literature on accounting for biodiversity and extinction accounting by exploring its historical roots.

\section{Gilbert White and his Naturalist's Journals}

Although there are many nature diarists, we decided to focus on Gilbert White, as he is a pioneer, being one of the first naturalists to record detailed observations in journal form, over a long time period. He is also one of the leading people in British history (and around the world) to record and name species. There are many nature diarists whom we could have selected over the last 300 years but White stands out as exceptional in terms of the accuracy of his recording, his focus on species of flora and fauna and his position historically as possibly the first biodiversity accountant. Diaries by Richard Jeffries (see Looker, 1941), (Adams, 1985) and the well-known pictorial Country Diary of an Edwardian Lady (Holden, 1980) may all be interpreted as early forms of biodiversity accounting by an interested party. 
Kilvert (1977), for example, is far more concerned with the lives of parishioners and with his own life than the life of the surrounding flora and fauna.

The Revd. Gilbert White was born on 18th July 1720 in Selborne, a village in Hampshire, in the United Kingdom. He was educated at Oriel College, Oxford (Clegg, 1975). Throughout his life, White kept records of his financial expenses and recorded daily observations of weather, flora and fauna, gardening-related information and other natural events that interested him. His recordings included his Garden Kalendar, his Flora Selborniensis, his Naturalist's Journals, which are the focus of this paper, and later, his widely celebrated Natural History and Antiquities of Selborne, which used his earlier Naturalist's Journals as source material. Across the centuries, it is possible to glean some sense of White's character, especially in relation to his Journals, through his own writing as well as through others'. He was scientific and objective in approach, and although there are aesthetic elements to his recording, he focussed on providing a "true and fair" view of the nature he observed:

No writer is less self-conscious and individualist, or more objective in the sense that his whole mind, heart and skill were devoted to revealing something quite outside himself ... he is a standing example of the truth of the artistic axiom that he who shall lose his personality shall save it (Massingham, 1920, p. 265).

White's meticulous character blended with a love of wildlife and nature, to engender records of scientific importance from a quarter of a millennium ago:

White's approach was a unique combination of beautifully close observations of the natural world around him, and an incisive, enquiring mind (Lawton, 1999, p. 476).

White was essentially a field naturalist and had little patience for contemporary tendencies by naturalists to collect specimens and to rely on others' writings. Rather, his passion was for empirical fieldwork, recording his own first-hand observations in a scientific manner (Mullett, 1969). He was viewed as unusual in the way he combined the character of an "exact scientist" with that of an "imaginative narrator" (Emden, 1948).

There are a number of ways in which White's Naturalist's Journals represent an early form of accounting for biodiversity and we discuss each in turn, specifically: (1) the ways in which his biodiversity accounts seemed to have evolved from his lifelong recording of more traditional financial accounts; (2) the ways in which he was "called to account" for flora and fauna as well as his motivations for accounting; (3) the accuracy of his accounting; and (4) the fact that his accounts were effectively audited: perhaps the first assurance of biodiversity accounting in history.

\subsection{White's biodiversity accounts developed from his financial accounting}

It is quite plausible that keeping a nature diary is similar to the keeping of financial accounts or bookkeeping. White kept financial accounts of his daily expenses [6]. At university, White recorded every type of payment from books and stationery to candles, sugar and tea in an account book (Emden, 1948). Academics, from a variety of disciplines, have drawn connections between White's proclivity to keep detailed financial accounts and the development of his far more famous nature diaries, arguing that the two forms of recording are similar. For example:

It seems that he kept meticulous accounts throughout his adulthood, and certainly from the time he proceeded to university. The discipline of maintaining such data over so many decades (in total, at least fifty years) illuminates ... the personal trait that was to serve him so well in the keeping of records about his observations in natural history (Foster, 1988, p. 12, emphasis added).

White had a natural tendency to account for his actions in the form of written records: 
AAAJ 33,8

1842
The accounts are models of neatness. Purchases of books, gunflints, powder-horns, spurs, wine, and tea, payment for boat hire, subscriptions to a "music club" are among the entries ... (Johnson, 1970, p. xx).

A general ledger records and categorises financial information by account, date and amount with cross-references or folios showing how the double-entry process was applied for each transaction. This logic is also applied, whether knowingly or otherwise, in the way White kept his records of species. Entries are organised chronologically and by date. Different ledger accounts for each element of financial reporting give way to different types of flora and fauna. Each observation is "allocated" to a species category in the same way that a transaction is analysed by the double-entry ledger system. Both the financial ledgers and White's records of species are periodically totalled, so that balances can be accumulated and compared. The nature diaries go far further than being simple records. Foster (1988) discusses the developmental importance of White's pre-1768 record-keeping behaviour. He uses White's detailed account of the construction of a "ha-ha" in his garden as exemplary of the scientific manner by which White breaks down processes into individual stages, stating that:

The point, however, lies ... not so much in the originality of what is observed, but in the willingness to accomplish the recording with a proper care and attention to accuracy ... and White was to achieve what he did because of his willingness to record (Foster, 1988, pp. 24-25).

\subsection{White "called to account"}

Several factors motivated White to keep his Naturalist's Journals. First, White had a passion and enthusiasm for the natural world and for natural history from childhood that led him to observe and record (Foster, 1988). Of more relevance, from an accounting perspective, is the fact that he was "called to account" when a lawyer, the Hon. Daines Barrington [7], sent him a copy of his Naturalist's Journals in order for him to complete it on a daily basis [8]. Barrington's Journal was effectively a template for accounting on nature, as its intention was to encourage naturalists around Britain to complete it daily such that a countrywide Natural Calendar may be compiled, demonstrating relationships between flora and fauna, weather and the countryside. The purpose of this exercise was to provide information that would be of use to naturalists, farmers and gardeners (Barrington, 1767; Foster, 1988) [9]. As well as Barrington's initial call for White to complete his Journal, he also encouraged him through regular correspondence and in meetings. Each page of the Naturalist's Journal consisted of seven rows, one for each day of the week. The data were then entered across three main categories, into 11 columns, described as contextual, seasonal and miscellaneous (Foster, 1988). The data required by the Journal's layout include: meteorological data such as temperature and rainfall; geographical data such as location and soil; seasonal data relating to leafing of trees, flowering of plants, appearance and disappearance of birds and insects and observations on fish and "other animals" (Foster, 1988). The last column requests that the diarist enter miscellaneous information and memoranda.

The information contained in White's Naturalist's Journals is not only relevant for natural scientists interested in changing ecologies but also for accounting as a mechanism of accountability and change. Similar to traditional record-keeping systems, White's Naturalist's Journals provide a qualitative "measure" of the state of natural capital at a point in time and how it has been adversely impacted by human activity (Jones, 1996). An organisation's inventory of species represents an important means of demonstrating environmental stewardship and allowing stakeholders to hold management accountable (Jones, 2003). By analogy, White provides a broader account of how human activity appeared to be affecting the natural world. We can draw parallels between the structure of the accounting schematic used for Barrington's Journal and modern-day accounting systems. The Journal may be interpreted as a consolidated natural record of a particular region (Cuckston, 2017) and a more complete account of the ecosystem, similar to aggregating economic activity of multiple subsidiaries to 
provide a view of the economic activity of a group of companies on the basis that they, in substance, are part of a single economic entity. Similarly, the idea of reporting on observations from different parts of the country is consistent with explaining how different geographical operations making up an organisation have performed at the heart of segmental reporting. The International Integrated Reporting Council (IIRC, 2013) refers to the need to report on different types of capital, of which natural capital is only one. White's Journal suggests an understanding, 300 years before the IIRC, that one-dimensional reporting is insufficient in providing a complete representation of the unit of account.

\section{Roots of accounting for biodiversity}

\subsection{The accuracy of White's accounts of biodiversity}

White's biographers discuss the accuracy of White's recordings across all of his manuscripts including his Naturalist's Journals, acknowledging,

... a compelling integrity. Just now and then one's eye is caught by a careful correction. In some cases these are for grammar or style ... but occasionally they are for accuracy ... They are significant pointers to a strict care for accuracy (Foster, 1988, p. 52).

Further, the accuracy of White's nature recordings has been emphasised in comparison to accounts by other naturalists, often criticised in the literature for romanticising their descriptions of the natural world:

In a few, rare cases the power of observation, and even more the later recording, remained as unclouded and undistorted as it did for Gilbert White (Allen, 1976, p. 47).

Indeed, White's accuracy in recording appears as a personal trait:

His exactness in all instances in which factors can be measured amounts almost to an obsession. He measures everything capable of mensuration, from animals and birds to liquids and solids ... His ability as a scientist was accompanied not only by exactness in reporting his observations, but also by an ardent curiosity which led to search for new facts, and to endeavour to obtain authenticated deductions (Emden, 1948, p. 114-115).

The tendency towards accuracy inherent in White's accounts also renders them more akin to financial accounts than to mere narrative records.

\section{4 "Auditing" White's biodiversity accounts}

As the one who called White to account through the completion of his Journal template, Barrington took a continued, active interest in White's "accounting for biodiversity" through the medium of his Naturalist's Journals, to the point where he conducted perhaps the first "audit" of a biodiversity account. White lent two of his completed Journals to Barrington so that he could see how he had completed them [10]. Although there is no evidence that White invited Barrington to write on his Journals, he covered the pages in annotations [11]. He made 11 comments on the manuscripts as well as crosses in red crayon and other marks. Foster (1988) states that the 1774 Journal was littered with Barrington's annotations and that clarification or verification was requested on about $15 \%$ of White's text, with around 70 items that the "auditor" asked White to reconsider [12]. Although this type of review is a far cry from the modern-day audit of financial statements, it is notable that early types of "auditing" involved one of the partners in a business venture reviewing the financial ledgers and crossreferencing recorded entries to source documents. Findings were discussed with fellow proprietors who were accorded the opportunity of furnishing additional information as required. Interestingly, these "audits" involved the accounting records being annotated as proof that they had been verified using different coloured ink (Watts and Zimmerman, 1983), a technique employed in Barrington's "audit". 
AAAJ 33,8

1844

\section{Research method}

The Naturalist's Journals of Gilbert White form the basis of our analysis. We analysed the Journals in two different ways. Our first approach involved extracting information relating specifically to species of flora and fauna and collating the frequency of recording, by species, for a period of eight years. This provided a "biodiversity account" from 250 years ago. White recorded the raw data, the transactional events from 1768 until his death in 1792. In Table 1, the frequency of sightings from 1768 to 1775 is recorded. The choice of this time frame for our research is based on the way in which White's Journals evolved over the 24-year period of recording. Until 1776, the Journals were in-keeping with Barrington's instructions and followed the Journal template laid out in a rigorous fashion. During the period from 1768 to 1775 , the recording followed this designated format and therefore resembled a formalised accounting, consistent from year to year, and collated in columns, like financial accounting. Throughout this eight-year period of recording, White made around 2,500 entries per year (Foster, 1988). From 1776 onwards, the style of recording changed, with White reducing the data he recorded in the Journals' columns and writing a more narrative discussion on broader topics (Foster, 1988).

We summarised the data from White's diary in terms of frequency of sightings of particular species rather than attempting to account for number of particular flora and fauna sighted. This is chiefly because of recording inconsistency: White sometimes documents, for example, the number of rabbits seen, but, at other times, mentions a flock of birds or a cluster of berries. The aim of producing this data in tables is not to present an accurate scientific account of the number of each species observed but rather to show the extent of species and the frequency of sightings. It also provides insights into White's observational diligence and recording priorities. The records used in compiling this paper are from an edited version of White's Naturalist's Journals, as this is the only available published source, produced in its first edition in 1931. Although the original manuscripts are housed in the British Museum, it would not, in our view, add to the current study if the authors were to analyse the manuscripts as there are around 70,000 entries (Foster, 1988), many unrelated to species [13]. Our aim is to provide an appreciation of the extent of species recorded and to demonstrate the ways in which the journal represents accounting for biodiversity, rather than to count and record every single entry. Further, the editing involved in producing the collection used in our study removed primarily any repetitive meteorological material rather than accounts of species sighted, as explained by Johnson (1970) [14]. However, Johnson does indicate (in the preamble) that he has in some places - reduced the number of entries relating to sightings of birds. This means that our data summary, in the form of a biodiversity account, is not representative of the entirety of White's entries (implying that we have an illustrative rather than a comprehensive set of data). Rather, it is an attempt to provide an account of the flora and fauna easily observable in his time and place. Such data issues are not unusual in the accounting history literature as primary records are often manipulated into a structured form in archives or even in published volumes. This can lead to data reduction for a number of reasons including, as in this case, the archivist's concern for space (Napier, 2002). In accounting, it is rare for the original transactional data to remain. More common are the bookkeeping records or the final financial statements. Detail may be lost through a process of increasing selectivity and abstraction as, over time, original events are interpreted through historians' narratives.

At a second level, we analysed the content of White's Journals using a narrative approach, involving a meaning-oriented content analysis that led to the drawing out of themes from the text. Our analysis of the accounts presented in the Journals involved a thematic and interpretive analysis, similar in style to the processing of interview data used in interpretive research. The analysis employs a narrative style consistent with a broadened view of accounting which accommodates a “...wide range of modes of calculation, record-keeping and reporting” (Napier, 2006, p. 7). Indeed, Napier (2006) describes a narrative style as follows: 


\begin{tabular}{|c|c|c|c|c|c|c|c|c|c|}
\hline Names of species as recorded by white & 1768 & 1769 & 1770 & 1771 & 1772 & 1773 & 1774 & 1775 & $\begin{array}{l}\text { Roots of } \\
\text { accounting for }\end{array}$ \\
\hline Angler's may-fly (may-fly) & & & & 2 & & & 1 & & biodiversity \\
\hline Ants & & 1 & 1 & & 1 & 2 & & 2 & \\
\hline Ants (flying) & 1 & 1 & & 1 & & & & & \\
\hline Aphides & & & & & & 2 & & & \\
\hline $\begin{array}{l}\text { Arbutus } \\
\text { Ash }\end{array}$ & 1 & & 1 & & & & & & 1845 \\
\hline Bank-martin (sand martin) & & & 9 & 1 & 1 & 2 & 1 & 2 & \\
\hline $\begin{array}{l}\text { Barrel-fly (Gad-fly/horse bot/oestrus } \\
\text { bovis/horsefly, ox warble fly) }\end{array}$ & 2 & & 2 & 1 & & & & & \\
\hline Bats (unspecified) & 1 & 1 & 1 & 1 & 1 & & & 1 & \\
\hline Bat (great) (vespertilio altivolans) & & & 1 & 1 & & & & 1 & \\
\hline Beeches & 2 & & & 2 & 2 & 1 & 1 & & \\
\hline Bees (unspecified) & 2 & 1 & 2 & & 1 & 3 & 1 & 2 & \\
\hline Bees (honey) & & & & & & & & 2 & \\
\hline $\begin{array}{l}\text { Bees (hoop shower) (carder) (apis } \\
\text { manicatas) }\end{array}$ & & & & & 1 & 1 & & & \\
\hline $\begin{array}{l}\text { Bees (long-horned) (apis longicornis) } \\
\text { (black, hairy burrowing) (Eucera } \\
\text { longicormis) }\end{array}$ & & & 1 & & 1 & & 2 & & \\
\hline Bees (Bombilius medius) & & & & & & & 4 & & \\
\hline Beetles (unspecified) & & & & & & & 1 & & \\
\hline Bird's nest orchis (ophrys nidus avis) & & & & & 1 & & 2 & & \\
\hline Bittern & & & & & & & 1 & & \\
\hline Black warty water-efts (triton cristatus) & 1 & & & & & & & & \\
\hline Blackbird & & & 2 & 1 & & 1 & & & \\
\hline Black cap (pewit gull) & & 1 & 2 & 3 & 3 & 1 & 2 & & \\
\hline Brambling & & & 1 & & & & & 2 & \\
\hline Brimstone butterfly (papilio rhamni) & & & 1 & & & 1 & & & \\
\hline Brown-eyed knapweed (centaurea jacea) & & & & & & 1 & & & \\
\hline Bullfinches & & & 1 & & & & & & \\
\hline Bunting (emberiza alba) & & 2 & 2 & 1 & & 2 & 2 & & \\
\hline Bustards & & 1 & 1 & & & 1 & & & \\
\hline Butcherbird (red-backed) & 1 & & & & 1 & & & & \\
\hline Butterflies (unspecified) & & & 1 & 1 & & & & & \\
\hline Butterflies (white) & 1 & & & & & & & & \\
\hline Buzzard & & 1 & & & & & 1 & & \\
\hline Calculus oegagropila & & & 1 & & & & & & \\
\hline Carp & & & & 1 & & & & & \\
\hline Chaffinch & & 3 & 2 & 1 & 2 & 4 & & 1 & \\
\hline Chiffchaff & 1 & 1 & & 1 & & & & & \\
\hline $\begin{array}{l}\text { Chrysomeleae Oleraceae (goldcrest) } \\
\text { (goldfinch) }\end{array}$ & 1 & 5 & 1 & 1 & 3 & & & & \\
\hline $\begin{array}{l}\text { Cockchafer/chafers } \\
\text { Codlings }\end{array}$ & & & 6 & & 2 & 1 & 6 & & \\
\hline Cole titmouse (Cole mouse/Cole tit) & & & & 1 & 1 & & & & \\
\hline Coltsfoot & & & 1 & & 1 & & & & \\
\hline Common milkwort & & & 1 & & & & & & \\
\hline Cowslip & & & 1 & & & & & & \\
\hline Creeper (tree-creeper) & & & & & & & & 1 & \\
\hline Crickets & 1 & & & & & & & & \\
\hline Cricket (field) & & & & & 2 & 2 & & & Table 1. \\
\hline Cricket (mole) & & 1 & 2 & 2 & 1 & & & & Gilbert White's \\
\hline Crocus Venus & & & 2 & & & & & 2 & biodiversity account \\
\hline Crossbeaks (crossbills/grossbill) & & & 2 & & & & & & 1768-1775. Species \\
\hline & & & & & & & & (continued) & $\begin{array}{l}\text { frequency of sightings } \\
\text { recorded each vear }\end{array}$ \\
\hline
\end{tabular}


Names of species as recorded by white

Crow (grey) (Royston) (cornix cinera)

Cuckoo (cuckow)

Cuckoo flower (cardamine pratensis)

Daddy long legs

1846

Daphne mezereon

Death watch beetle

Dog's Mercury

Downy woundwort

Dragon-flies

Dropwort (Spirea filipendula)1

Ducks (unspecified)

Dun diver Mergus serratus Actually

female goosander, mergus merganser)**

Dutch plaise

Earwigs

Elder

Elms

Empedes

Fake hellebore

Fallow deer

Fern owls (nightjars) (caprimulgi)

(goatsuckers)

Field-fares

Fleas

Fly (flesh) (musca canaria)

Flies (dust)

Fly (musca meridiana)

Fungus (edible) Helvella crispa

Flies (unspecified) (muscae)

Fly (tenax)

Fly (forest)

Fly (stinging)

Flycatcher (stoparola)

Foxglove

Fragrant orchis

Frogs

Fungus (unspecified)

Glow worms (lampyris noctiluca)

Gnats

Golden apple beetles (chrysomela

gottingensis)

Golden saxifrage (opposite leaved)

1768

1769

1770

1771

$\begin{array}{lllllll}2 & 1 & 1 & & 2 & 2 & 1 \\ & 3 & 1 & 1 & & 1 & \end{array}$

1

(chrysoplenium oppositifolium)

Gossamer

Goose-berry

Grass snake (common) (Coluber natrix)

Grasshopper

Grasshopper warbler (Grasshopper lark)

Great titmouse (parus major)

Green-finches

Green hellebore

Green plovers, lapwing

Green sandpipers

Green woodpecker

$\begin{array}{ll}1 & 1 \\ 1 & 1 \\ 2 & 1\end{array}$

1

1

1

1

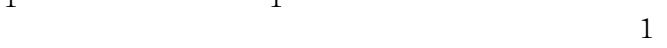




\section{Names of species as recorded by white}

\section{8}

Groundsel

Gulls (unspecified)

Gull (great black and white)

Hares

Hawk

Hawkmoth (eyed or humming bird moth)

Hazel (corylus avellana)

Hedgehog

Hedge sparrow

Helleborus foetidus

Herring

Horse chestnut

House sparrow

Holly

Ice bears

Ichneumonfly

Ilexi

Ivy (hedera helix)

Jackdaw

Jays

Juniper (red American)

Kite (milvus aeruginosis)

Larks

Laurels

Laurustines

Lepismae (silver-fish)

Lime

Ling

Linnets

Lizard (lacerta)

Long-tailed titmouse

Lungwort (pulmonaia officinalis)

Magpies

Marsh titmouse

Martins (house) (hirundo domestica)

Merulae torquatae, ring-ouzel

Mezereon (daphne as above)

Michaelmass daisy

Missel thrush

Moles

Moorhen

Mulberry

Muscae (flies)

Musk thistle

Nightingale (Luscinia)

Nuthatch

Oaks

Oestrus curvicauda

Owls (unspecified)

Owls (white)

Papiliones (butterflies unspecified)

Papilio urticae

Partridges

Peacock butterfly

1

1

1

1

1

1

1

1

1

2

2

1

2

$\begin{array}{lll} & 1 & 1 \\ & 1 & \\ & & 1\end{array}$

1

1

$\begin{array}{llllllll}1 & 4 & 1 & 2 & 2 & 1 & 1 & \\ & & & & & 1 & 1\end{array}$

1

Roots of accounting for biodiversity

1

1

1

$\begin{array}{llllll} & 1 & 1 & & 1 & \\ & 1 & 1 & 2 & 1 & 3\end{array}$

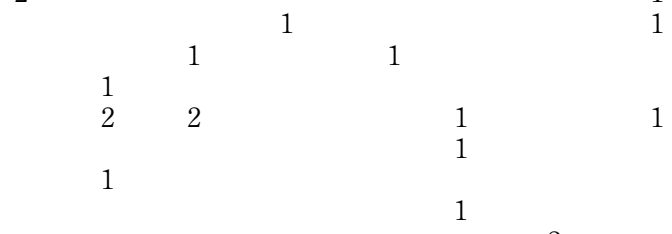

$\begin{array}{rrrrrrrr}1 & & 2 & & & 1 & 2 & \\ 4 & 4 & & 7 & 11 & 7 & 20 & 7 \\ 2 & 3 & 5 & 3 & 4 & 4 & 3 & 1 \\ & 1 & & & & & & 1\end{array}$

$\begin{array}{lll}1 & 1\end{array}$

$\begin{array}{llllll}1 & 2 & 4 & 1 & 1 & 2\end{array}$

1

$\begin{array}{lll}1 & 1\end{array}$

$\begin{array}{llllllll}2 & 1 & 2 & 2 & 1 & 1 & 2 & 1 \\ 2 & 1 & 1 & 3 & 1 & 1 & \end{array}$

$\begin{array}{lllllll}2 & 1 & 1 & 3 & 1 & 1 & 1\end{array}$

1

1

$\begin{array}{llllll} & 1 & 1 & & & 1 \\ 1 & 1 & 1 & 2 & 1 & 1\end{array}$

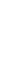

2

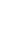

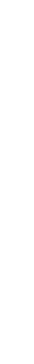

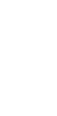


$\underline{\text { Names of species as recorded by white }}$

$\begin{array}{llll}1768 & 1769 & 1770 & 1771\end{array}$

Phalaenae (Lepidoptera) Moths

Pheasant (eyes)

\section{1}

$3 \quad 1$

Phyryganeae

Pigeons

Pike

Plover, green whistling (golden plover)

1848

Plum weevil (curculio)

Primrose

Ptinus pectinicornis (maggots)

Quail

Rabbits (black)

Raven

Red admiral butterfly

Red-breast

Red-start

Red wings

Reed-sparrow (reed warbler?)

Rimes

Ring dove

Rooks

Round-leaved rampion

Rowan

Sandpipers

Sanicle (sanicula europaea)

Scarabaeus solstituales

Seagull (large)

Sedgebird

Shell-less snails (blacksnail) (slugs?)

Shepherd's rod

Side fly

Six-spot burnet moth

Spiders (unspecified)

Snipe

Song thrush

Snails (house) (shell snails)

Snakes' head fritillary (fritillaria

imperialis meleagris)

Sparrows (unspecified)

Snake-weed

Snowdrops

Spotted water rail (rallus aquaticus**)

Spiders

Starlings

Stinkhorn (phallus impudicus)

Stone curlew (oedicnemus)

Swallow (hirundo agrestis)

Swallow-tail butterfly

Swan

Swan-goose

Swift (hirundo apis)

Teal

Tench

Thrush

Tipulae
2

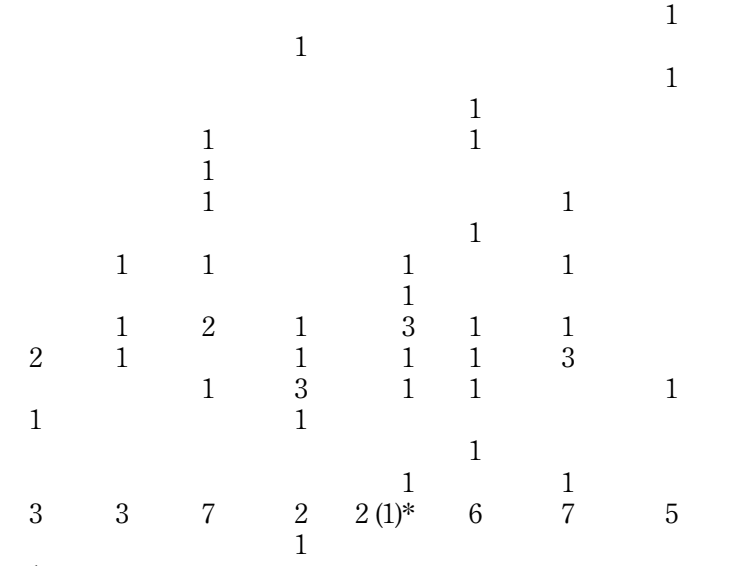

1

1<smiles></smiles>

$\begin{array}{llll}1 & & 1 & 1\end{array}$

$\begin{array}{rrrr}1 & 5 & & 1 \\ 7 & 2 & 8 & 14\end{array}$

$\begin{array}{lll}1 & 1 \\ 1 & 1 & 1\end{array}$

$\begin{array}{lll} & 1 & \\ 1 & 4 & 5 \\ & & 1\end{array}$

$\begin{array}{lll}1 & 1 & 1\end{array}$ $\begin{array}{rrrr} & 2 & 1 & 2 \\ 13 & 9 & 13 & 7\end{array}$

$\begin{array}{llll}1772 & 1773 & 1774 & 1775\end{array}$

2

2

1

1

1

5

1

4

1

1

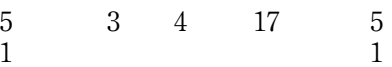

$\begin{array}{llll}1 & 1 & 1 & \\ & & 1 & 2\end{array}$

Table 1. 


\begin{tabular}{|c|c|c|c|c|c|c|c|c|c|}
\hline Names of species as recorded by white & 1768 & 1769 & 1770 & 1771 & 1772 & 1773 & 1774 & 1775 & $\begin{array}{l}\text { Roots of } \\
\text { accounting for }\end{array}$ \\
\hline Titlark (Tree Pippet) & 1 & & 2 & 1 & 1 & 3 & 1 & & biodiversity \\
\hline Toad & 1 & & & & & & & 1 & \\
\hline Tom-tit & & & & & 1 & & & & \\
\hline Toothwort (Lathraea squammaria) & & & & & & 1 & & & \\
\hline Trout & & & & 1 & & & & & \\
\hline Truffles & & & 1 & & & 1 & 1 & 1 & 1849 \\
\hline Turn-pikes & & & 1 & & & & & & \\
\hline & & & & 1 & 1 & 1 & $\begin{array}{l}1 \\
1\end{array}$ & & \\
\hline Vetch & & & & 1 & & 1 & & & \\
\hline Violets & & & & & & & & 1 & \\
\hline Viper (coluber berus) & 1 & & 1 & & & & & 1 & \\
\hline Viper's bugloss & & 1 & & & & & & & \\
\hline Wagtails (unspecified) & & & & & & 1 & & & \\
\hline Wasps & 1 & & & & 3 & 4 & 1 & $\begin{array}{l}\text { wasp } \\
\text { plague }\end{array}$ & \\
\hline Wheat-ear & & & & 1 & & 1 & & & \\
\hline White throat & & 1 & 1 & 1 & 1 & & 3 & 1 & \\
\hline Grey wagtail & & & & & & 2 & & & \\
\hline White wagtail & & 1 & 1 & & & & & & \\
\hline Wagtail (water) (albino) & & & & & & 1 & & 1 & \\
\hline White bryony & & & & & & 1 & & & \\
\hline Whitebeam tree & & & & & & 1 & & & \\
\hline Whitings & & & & 1 & & & & & \\
\hline Whitlow grass & & & 1 & & & & & & \\
\hline Wigeon & & & & 1 & & & & & \\
\hline Wild fowls/wild ducks (unspecified) & & & & & 1 & 1 & 1 & & \\
\hline Wild geese & & & 1 & & 1 & & & & \\
\hline Willow wren & & 1 & & & 1 & 1 & 1 & & \\
\hline Windhover or "kestril" & & & & & & & & 1 & \\
\hline Winter aconite (wolfs bane) & & & & & 1 & & 1 & & \\
\hline Witches' butter (tremella nostoc) & & & & & & & & & \\
\hline $\begin{array}{l}\text { Wolf fly (robber fly) (Asilus } \\
\text { crabroniformis) }\end{array}$ & & & & & & & & & \\
\hline Wood anemone (anemone nemorosa) & & & & & & 1 & & & \\
\hline Woodcock (scopolax) & 1 & & & 2 & 1 & 2 & 1 & 2 & \\
\hline Woodlark & 1 & 1 & 2 & 2 & 1 & 2 & 1 & & \\
\hline Woodlice & & & & 1 & & & & 1 & \\
\hline Woodpecker (unspecified) & & & & & 1 & & & & \\
\hline Wood pigeons (Stock doves) (oenas) & 2 & 2 & 1 & & 1 & 1 & & & \\
\hline Wood-sanicle & & & 1 & & & & & & \\
\hline Wood sorrel & & & 1 & & & & & & \\
\hline Wood wren & & 1 & & 1 & 1 & & & 1 & \\
\hline Worms (unspecified) & & 1 & & & & & & & \\
\hline Worms (Earth) & & & & 1 & & & 2 & 4 & \\
\hline Worms (blood) & & 1 & & & & & & & \\
\hline Wornils & & & 1 & & & & & & \\
\hline Wren & 1 & 1 & 2 & & 3 & & & & \\
\hline Wryneck (Inyx) & 1 & 1 & & 1 & 1 & & 1 & & \\
\hline Yellow hammer & 1 & 1 & 1 & & & & & & \\
\hline Yellow pimpernel (lysimachia nemorum) & & & & & & 1 & & & \\
\hline Yew (taxus baccata) & & & 1 & & & 1 & & & \\
\hline \multicolumn{9}{|c|}{ Note(s): *accounted for but dead, **accounted for but dead by shooting } & Table 1. \\
\hline
\end{tabular}


AAAJ 33,8

1850

first, a general issue is identified at the beginning of the paper, giving rise to questions or puzzles. The body of the paper addresses the puzzles and "closes the loop". The narrative method is also consistent with a social constructivist perspective of how accounting systems function (Hopwood, 1987) and the possibility of their emancipatory potential (Gallhofer et al., 2015). We apply a similar methodological style to analysing White's Naturalist's Journals. We produce data from the journal as illustrative extracts, summary data and aggregated data. The construction of the narratives, combined with the summary biodiversity accounts, provides a means of analysing the accounts in terms of their underlying motivation (e.g. data collection, aesthetics and social emancipation). As part of this process, the analysis draws on biographies of White, analyses of White's work in the literature and detailed discussion of the Journals from an accounting perspective. As a final stage of analysis, we seek to compare White's account of species to current data on populations and extinction risk.

\section{An analysis of White's Naturalist's Journals as early forms of biodiversity accounting}

The biodiversity accounts that we present in Table 1 provide a summary of flora and fauna recorded by White in his Naturalist's Journals. We omitted references to garden plants and vegetables (farming produce), as they are cultivated rather than wild species. We omitted trees as their numbers are more stable, focussing our analysis on animals, insects, birds and wild flowers and plants.

We also found a number of themes arising from our analysis of White's Journal, including: the evolution of White's accounting over time; aesthetic elements in White's accounts; and some problematising and emancipatory elements of the accounts, as discussed further.

\subsection{The evolution of White's accounting over time}

Over time, the recording becomes more detailed and accurate leading to additional data collection and provision of a more complete data set. Diaries are often kept over long time periods, showing evidence of deeper knowledge and more refined diary-keeping techniques. In this way, the Naturalist's Journals, like traditional accounting systems, are methodologies for observing and reporting details that become more refined through a process of mistakes, revision, experimentation and learning (see Hopwood, 1987). As the record-keeping techniques become well established and the accounts become more sophisticated, they give rise to new fields of enquiry and the identification of different subject matter (Burchell et al., 1980; Hopwood, 1987). For example, accounting for biodiversity is a process that can lead to the discovery of new species. We found several cases of the discovery of new species in the process of collecting information. For example:

It was Gilbert White, God rest his soul, who first distinguished the willow warbler from the chiffchaff (Adams, 1985, p. 52).

Indeed, White was first to realise that there were three species of willow wren, not one, as believed at the time: willow warblers, wood warblers and chiffchaffs (Lawton, 1999). In the Natural History and Antiquities of Selborne (White, 1788), based on the data recorded in his Journals, White was the first to provide a detailed account of the harvest mouse in England (Mullett, 1969). This shows how the Naturalist's Journals resonate with financial accounting in the way that they not only improve in accuracy over time [15] but expand the field of observation by facilitating the identification and labelling of different "elements" of the subject matter under review. The Journals highlight this by demonstrating the importance of the accounting function in discovering new or hidden information and in developing terminology for subject matter, comparable to the processes used to define "assets" and other conventional accounting terms. A similar phenomenon is explained by Hopwood (1987), albeit in a conventional business context, where cost accounting (developed for a specific 
purpose) soon gives rise to the emergence of new forms of economic visibility which inform production, marketing and selling decisions in unanticipated ways. When it comes to the Naturalist's Journals, White's personal (and relatively informal) records evolve unexpectedly into more sophisticated records or data sets that transcend the recording of "number of species" to the categorisation of fauna and fauna and the identification of new organisms. If we apply Hopwood's (1987) theorisations to this dynamic form of accounting, the accounts have the potential to inform future lines of accountability by highlighting changes in natural capital previously unreported by conventional reporting frameworks.

\subsection{Aesthetic elements of White's biodiversity accounts}

White was a naturalist more inclined towards scientific recording rather than fanciful, romanticised description (Foster, 1988). However, there is evidence of aesthetic narrative accounting of nature and species in his Journals. This element increases over time and especially after the change in recording style from 1776 onwards. White's more emotional and aesthetic side emerged in his Natural History of Selborne, which derives from his Journals but is far more romanticised for the general reader, rather than being a list of observational notes. The aesthetic element of the recording means that the Journals transcend scientific data collection exercises. The aesthetic "element" of White's accounts should not be overlooked. As explained by Atkins et al. (2015), thinking about a future where society is in perfect balance with the natural world and contrasting this with the environmental unsustainability of the present provides a frame of reference for highlighting current shortcomings in our corporate governance paradigms and a basis for offering normative recommendations. Recent literature on accounting for biodiversity, especially extinction accounting, has emphasised a need for an accounting which is hybrid and collates different forms of accounting for species including narrative description and aesthetic elements (Atkins and Maroun, 2018; Cuckston, 2018; Gray and Milne, 2018).

The 18 th century also witnessed the emergence of the Picturesque aesthetic movement, as defined and developed by artists and writers such as William Gilpin (Atkins and Atkins, 2018). The Picturesque aesthetic involved framing scenery, landscape and nature within the evolving societal and industrial context of the time and could take the form of narrative description as well as of paintings and etchings [16]. Despite the scientific nature of White's Journals, there are elements of his writing that emphasise an inherent aesthetic element to his recordings of flora and fauna. For example, Fussell (1990) comments that the vocabulary and detail used in White's recordings are "reminiscent of a Picturesque composition", where he uses words such as, "lovely", "graceful" and "engaging", which bring out the aesthetic elements to his naturalist observations:

... White's comments blend a Picturesque taste with a more pragmatic and scientific interest (Fussell, 1990, p. 17).

\subsection{Problematising nature}

White's Naturalist's Journals record and catalogue information and thereby provide him with an opportunity to reflect on those observations. His account of nature raises environmental concerns, for example:

Blue mist. Vulg. Called London smoke ... This mist has a strong smell, and is supposed to occasion blights. When such mists appear they are usually followed by dry weather. They have somewhat the smell of coal-smoke and therefore are supposed to come from London as they always come to us with a N:E: wind (White, in Johnson, 1970, p. 24).

These quotations referring to "blue mist", commonly known as "London smoke", bear similarities to John Ruskin's diary, which took the form of a narrative account of clouds for a

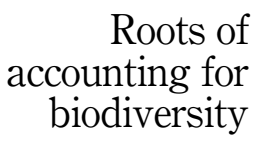

1851 
AAAJ 33,8

1852

long period of time, summarised in lectures on the "Stormcloud of the Nineteenth century", written a hundred years later. His lectures mentioned a "plague cloud", which was "always dirty, never blue". This may represent one of the earliest accounts of industrial pollution in the atmosphere, although it is also associated with the effects of a contemporary volcanic eruption:

The first time I recognised the clouds brought by the plague-wind as distinct in character was in walking back from Oxford ... in the early Spring of 1871 (Ruskin, 1884, p. 32).

White's Journals can be seen as descriptive accumulations of a diarist's observations (Gallhofer and Haslam, 2003), but they also provide a point of reference for reflections on the state of nature several years, decades or generations after the entries were made. In essence, they provide a chronology of nature that may be used to juxtapose the current and historic state of flora and fauna. Importantly, a seemingly neutral observation by White at one point in time can provide evidence of humanity's adverse environmental impact when re-assessed with the benefit of accumulated knowledge and scientific developments. By problematising biodiversity loss, the Naturalist's Journals can become part of drive for change. As scientific accounts of the natural world are more widely distributed and gradually internalised by stakeholders, they are giving rise to new forms of environmental activism. The Intergovernmental Panel on Climate Change (2013) and WWF (2018), for example, take cognisance of mounting scientific evidence of the impact of human activity on the planet and use this data to create awareness of a looming environmental disaster, lobbying for urgent reform. Similarly, a growing body of environmental accountants draw connections between data on biodiversity loss and corporate activity to hold companies accountable for their environmental performance, highlight the relevance of natural capital in a commercial context and advocate for revisions to existing accounting systems (Gray, 2010; Tregidga et al., 2014; Atkins et al., 2015). Writers have commented on the potential for White's works to offer a

... compelling "historical memory" of ecological engagement that operates counter-hegemonically to resist damaging abstraction (Williams, 2017, p. 434)".

This historical "memory" provides the basis for comparative accounting between the 18th century and now. White's writings also identified the impact of the Icelandic volcanic eruption on his local ecosystem and its flora and fauna. Although this environmental event was not linked to human activity, he nevertheless problematised the fragility of the natural world, its interdependent species and their vulnerability to sudden climatic changes (Scott, 2011).

\subsection{The social and emancipatory impact of White's Journals}

Social and emancipatory impacts arose from White's Journals and his related writings both during his life and since his passing. For example, his nature recording engendered the keeping of similar Journals by others. White's brother, chaplain to the garrison in Gibraltar for most of his working life, was encouraged and tutored by Gilbert, to produce a similar naturalist's journal covering species of flora and fauna inhabiting the Rock of Gibraltar. White increasingly frequented social circles in London as he grew older and visited his brother Benjamin's bookshop in Fleet Street, a meeting place for naturalists, as Benjamin White ran the leading publishing house for natural history books (Clegg, 1975). There were also important scientific publications arising from White's Journals, specifically two groundbreaking papers on swallows and martins which were read and later published by the Royal Society, demonstrating the serious consideration of White's work in his lifetime.

As well as the contemporaries of White, who corresponded regularly with him on issues of nature study, including Barrington and Thomas Pennant (whose letters were immortalised in The Natural History and Antiquities of Selborne) and other naturalists were strongly influenced by his work after his passing. A notable example is Charles Darwin, the famous naturalist, who produced The Origin of Species. He was influenced significantly by White's 
work, producing a book devoted to earthworms that was likely inspired by White's work on the same (Foster, 1988) [17].

White's work more generally has attracted great interest from naturalists over the 230 years since his passing. The Natural History and Antiquities of Selborne was referred to as possibly the "original textbook in behavioural ecology" (Foster, 1988). As mentioned earlier, the Naturalist's Journals were the primary source for material (Clegg, 1975) in addition to letters written between White and Pennant, and White and Barrington, drawn on for this book. The "Natural History" has been published in over 200 editions, reprinted in German, French, Danish and Japanese (Clegg, 1975; Martin, 1934). Indeed, it is claimed to be the fourth most published book in the English language (Clegg, 1975). White has been referred to as “...the great observational naturalist still so justly celebrated...” (Clegg, 1975). More recently, he was also described as "Naturalist Extraordinaire" (Egerton, 2007), and another commentator described the Natural History and Antiquities of Selborne as:

... the one literary classic, universally acknowledged, that the subject [natural history] . . has so far managed to produce and (apart from The Origin of Species) its one native sacred text (Allen, 1976, p. 44).

White's Naturalist's Journals, as encapsulated in The Natural History and Antiquities of Selborne, did not influence naturalists alone but also had a significant impact on the literary world, with many writers and poets familiar with, and in praise of, his work, including Auden, Carlyle, Coleridge, Ruskin, Woolf and Wordsworth (Menely, 2004; Williams, 2017). His work had a significant influence on 19th-century Victorian Society, as:

For nineteenth-century readers, White's Selborne was a seminal text of nature writing, exemplary in its observation of flora and fauna, its appreciation of local environments and its nascent ecology (Peterson, 2010, p. 80).

\section{From White's accounting for biodiversity to a Whitean extinction account}

White's biodiversity account provides data that lend themselves to comparison with current scientific evidence on species in the British Isles, allowing the creation of a longitudinal extinction account. We do, however, acknowledge problems with this approach, as it may be considered unrealistic to compare one man's recordings of his country rambles in an English county with national and global survey data. There is clearly a mismatch here in terms of scale. However, given the historic nature of his recordings and the lack of any other biodiversity recordings from this period, we feel that this (significant) limitation should not preclude such a comparison. The latest scientific research provides chilling evidence of sharp global declines in species of fauna since the 1970s. Although White obviously could not use similar methods to current scientific researchers and entomologists (as these had not been invented in his time), he provided basic observational data on a daily basis over many years, not in the 1970s but in the 1770s. It is also worth commenting that the type of detailed observation and recording conducted by White 250 years ago is an early precursor to the type of biodiversity surveying carried out by scientists at present. His accounting forms the basis of the historical development of species observation and tracking, making, in our view at least, these diary entries a reasonable - indeed the only - basis for comparison over such a lengthy period of time. The biodiversity account extrapolated from White's Journals in Table 1 allows a species-by-species comparison with current species' status in order to gauge the "health" of species populations. White's accounting for biodiversity provides us with detailed information forming a basis for comparison over a quarter of a century for a corner of the British Isles. Such an interdisciplinary approach shows the importance of recording and accounting for biodiversity across time as an emancipatory call for action.

In Table 2, we present the status of species recorded by White using available sources referenced primarily from web searches [18]. The research was time-consuming as many of 


\section{AAAJ 33,8}

Names of species as recorded by White (with updated names in brackets)

Angler's may-fly (common mayfly, green drake mayfly, ephemera danica)

Arbutus (strawberry tree)

Bank-martin (sand martin) (riparia riparia)

Barrel-fly, Gad-fly/horse bot/oestrus bovis/

horsefly

Bat (great), vespertilio altivolans (vespertilio murinus)

Bees, hoop shower, carder, apis manicatas (common carder bee, bombus pascuorum)

Bees, long-horned, black, hairy, burrowing, apis longicornis, eucera longicornis

Bee, Bombilius medius (bombylius medius) (bee fly?)

Beetles (unspecified)

Bird's nest orchis, ophrys nidus avis, (neottia nidus-avis)

Bittern (botaurus stellaris) (Eurasian bittern)

Black warty water-efts, triton cristatus

(Northern crested newt, great crested newt, warty newt)

Blackbird (turdus merula, common blackbird)

Black cap, pewit gull (larus ridibundus, blackcap sea gull)

Brambling (fringilla montifringilla)

Brimstone butterfly, papilio rhamni (Gonepteyx rhamni)

Brown-eyed knapweed, centaurea jacea (common knapweed)

Bullfinches (pyrrhula pyrrhula)

Bunting, emberiza alba (snow bunting, plectrophenax nivalis)

Bustards (otis tarda, great bustard)

Butcherbird, red-backed (red-backed shrike, lanius collurio)

Buzzard (buteo buteo)

Caprimulgus, fern owl, goatsucker (nightjar, caprimulgus europaeus)

Chaffinch (fringila coelebs)

Chiffchaff

Chrysomeleae Oleraceae, goldcrest (carduelis carduelis)

Cockchafer/fern chafers (Melolontha melolontha, may bug)

Table 2.

Cole titmouse, Cole mouse, Cole tit (periparus ater)
Extinction status of specific species and population trend

Least concern, widespread (NECR193, 2016)

Least concern, stable (IUCN)

Least concern, decreasing (IUCN)

Population swelled in 2018 UK heatwave (Telegraph)

Least concern, stable (occasional migrant visitor in UK)

(IUCN)

UK common and widespread (Nature Spot website)

UK Section 41 Conservation Priority Species (Buglife website)

Significant decline (Bumblebee conservation trust website)

No data available except on Linnaeus 1758

Least concern, decreasing (IUCN)

Least concern, decreasing (IUCN)

UK conservation status amber (RSPB website)

Least concern, decreasing (IUCN)

Least concern, increasing (IUCN)

Least concern, population trend unknown (IUCN)

Least concern, decreasing (IUCN)

UK low conservation priority, not threatened (Butterfly

Conservation website)

UK common status, widespread (The Wildlife Trusts website)

UK conservation status amber (RSPB website)

Least concern, decreasing (IUCN)

UK conservation status amber (RSPB website)

Vulnerable, decreasing (IUCN)

Reintroduced in the UK recently following earlier

extinction (RSPB website)

Least concern, decreasing (IUCN)

UK conservation status red

Commonest raptor in the UK (RSPB website)

Least concern, decreasing (IUCN)

UK conservation status amber (RSPB website)

Least concern, increasing (IUCN)

UK conservation status green (RSPB website)

Least concern, increasing (IUCN)

UK conservation status green

Widely distributed, common in the UK (Buglife website)

UK conservation status green 
Names of species as recorded by White (with updated names in brackets)

Coltsfoot (tussilago farfara)

Common milkwort (polygala vulgaris)

Cowslip (primulas veris)

Creeper, tree-creeper (certhia familiaris)

Cricket, field (gryllus campestris)

Cricket, mole (gryllotalpa gryllotalpa)

Crossbeaks, crossbills, grossbill (loxia curvirostra)

Crow, grey, Royston, cornix cinera (corvus cornix, hooded crow)

Cuckoo, cuckow (cuculus canoris)

Cuckoo flower, cardamine pratensis (Lady's smock)

Daddy long legs (tipulidae)

Death watch beetle (Xestobium rufovillosum)

Dog's Mercury (Mercurialis perennis)

Downy woundwort (stachys germanicus)

Dun diver Mergus serratus, female goosander, mergus merganser)

Earwigs (Forficula auricularia)

Fallow deer (dama dama)

Field-fares (fieldfare, turdidae)

Fly, musca canaria (common flesh fly, sarcophagi canaria)

Fly, musca meridiana (messembrina meridian, noon fly)

Foxglove (digitalis purpurea)

Fragrant orchis (common fragrant orchid,

Gymnadenia conopsea)

Glow worms (lampyris noctiluca)

Gold-crested wren (goldcrest, regulus regulus)

Golden saxifrage (opposite leaved)

(chrysoplenium oppositifolium)

Grass snake, common, Coluber natrix

Grasshopper warbler, Grasshopper lark

(Locustella naevia)

Great titmouse, parus major (great tit)

Green-finches (carduelis choris)
Extinction status of specific species and population trend

UK conservation status common (The Wildlife Trusts website)

UK conservation status common (The Wildlife Trusts website)

UK conservation status green (Plantlife website)

Least concern, stable (IUCN)

UK conservation status green (RSPB website)

UK vulnerable status following reintroduction and near extinction (Buglife website)

Critically endangered, only one small population (Buglife website)

Least concern, stable (IUCN)

UK conservation status green (RSPB website)

UK conservation status green (RSPB website)

Least concern, decreasing (IUCN)

UK conservation status red (RSPB website)

UK conservation status common (The Wildlife Trusts website)

UK conservation status common (The Wildlife Trusts website)

UK conservation status common (The Wildlife Trusts website)

UK conservation status common (The Wildlife Trusts

website)

Rare in the UK (Kew gardens online)

UK conservation status green (RSPB website)

Conservation status common (The Wildlife Trusts

website)

Least concern (IUCN)

Least concern, stable (IUCN)

UK conservation status common

Conservation status common (The Wildlife Trusts website)

UK conservation status common (The Wildlife Trusts website)

UK conservation status common (The Wildlife Trusts website)

UK conservation status common (The Wildlife Trusts website)

UK conservation status common (The Wildlife Trusts website)

Protected in the UK under the Wildlife and Countryside

Act, 1981. Priority Species under the UK Post-2010

Biodiversity Framework (The Wildlife Trusts website)

UK conservation status red (The Wildlife Trusts website)

Least concern, rising (IUCN)

UK conservation status green (RSPB website)

\section{Roots of accounting for biodiversity}

1855 
AAAJ 33,8
Names of species as recorded by White (with updated names in brackets)

Green plovers (lapwing, peewit, vanellus vanellus)

Green sandpipers (Tringa ochropus)

Green woodpecker (picus viridis)

Hares (lepus europaeus, brown hare, European

hare)

Hawfinch, grosbeak (Coccothraustes

coccothraustes)

Hawk (sparrowhawk)

Hawkmoth, eyed or humming bird moth

(Macroglossum stellatarum)

Hedgehog (erinaceus europeaus)

Hedge sparrow (prunella modularis, dunnock)

Hornet (Vespa crabro)

House sparrow (passer domesticus)

Ichneumonfly (Rhyssa persuasoria, sabre wasp)

Jackdaw (corvus monedula)

Jays (garrulous glandarius)

Kite, milvus aeruginosis (red kite, milvus milvus)

Larks (skylark, alauda arvensis)

Lepismae (Lapisma saccharinae, silverfish)

Linnets (carduelis cannabina)

Long-tailed titmouse (long-tailed tit, Aegithalos

caudatus)

Magpies (pica pica)

Marsh titmouse (marsh tit, Poecile palustris)

Martins, house, hirundo domestica (delichon urbicum)

Mayflies
Extinction status of specific species and population trend

UK conservation status red (RSPB website)

UK conservation status amber (RSPB website)

UK conservation status green (RSPB website)

Least concern, population decreasing (IUCN?)

UK conservation status red (RSPB website)

Least concern, increasing (IUCN)

UK conservation status green (RSPB website)

Least concern, stable (IUCN)

UK conservation status - migrant (The Wildlife Trusts

website)

Priority species under the UK Biodiversity Action Plan

(Game and Wildlife Conservation Trust)

Least concern, stable (IUCN)

Classified in the UK as Amber under the Birds of

Conservation Concern 4: the Red List for Birds (2015) (The

Wildlife Trusts website)

Least concern, decreasing (IUCN)

UK conservation status common (The Wildlife Trusts website)

UK conservation status red (RSPB website)

Least concern, decreasing (IUCN)

Local but fairly frequent and widespread in Britain

(Nature Spot website)

UK conservation status green (RSPB)

Least concern, stable (IUCN)

UK conservation status green (RSPB website)

UK conservation status amber (RSPB website)

Red kites were persecuted to extinction throughout the

UK, with the exception of Wales, during the 19th century.

In Wales, during the 20th century, the small population

was carefully protected. Red kites have slowly increased in numbers and range since the Second World War

Read more at https://www.rspb.org.uk/our-work/

conservation/conservation-and-sustainability/

safeguarding-species/case-studies/red-kite/

\#xhiIEuljWyWMIghs.99

Near threatened, decreasing (IUCN)

UK conservation status red (RSPB website)

Least concern, decreasing (IUCN)

UK wildlife status common (The Wildlife Trusts website)

UK conservation status red (RSPB website)

UK conservation status green (RSPB website)

Least concern, stable (IUCN)

UK conservation status green (RSPB website)

UK conservation status red (RSPB website)

Least concern, decreasing (IUCN)

UK conservation status amber (RSPB website)

Table 2.

(continued) 
Names of species as recorded by White (with updated names in brackets)

Meadow saffron

Merulae torquatae (ring ousel, turdus torquatus, ring ouzel, rock ouzel)

Missel thrush (turdus viscivorus, mistle thrush)

Moles (talpa europaea)

Moorhen (gallinule chloropus)

Nightingale, Luscinia (Luscinia megarhynchos)

Nuthatch (sitta europaea)

Papilio urticae (small tortoiseshell, aglais urticae)

Partridges (Perdix perdix, grey partridge)

Peacock butterfly

Pheasant

Plover, green whistling, golden plover (pluvialis apricaria)

Quail (Coturnix coturnix)

Raven (corvus corax)

Red admiral butterfly (Vanessa atalanta)

Red-breast (erithacus rubicula, Robin)

Red-start (phoenicurus phoenicurus)

Red wings (turdus iliacus, redwing)

Reed-sparrow (reed bunting, Emberiza

schoeniclus)

Ring dove (collared dove, Streptopelia decaocto)

Rooks (Corvus frugilegus)

Sandpipers (Actitis hypoleucos)

Sedgebird (sedge warbler, Acrocephalus

schoenobaenus)

Six-spot burnet moth (Zygaena filipendulae)

Snipe (gallinago gallinago)

Song thrush (turdus philomelus)

Spotted water rail, rallus aquaticus

Starlings (stellus vulgaris)

Stone curlew, oedicnemus (Burhinus oedicnemus)

Swallow, hirundo agrestis (hirundo rustica)

Swallow-tail butterfly (Papilio Machaon)

Swift hirundo apis (apus apus)

Teal (anas crecca)

Titlark, Tree Pippet (tree pipet, Anthus trivialis)
Extinction status of specific species and population trend

UK conservation status red (RSPB website)

Least concern, stable (IUCN)

UK conservation status red (RSPB website)

Least concern, decreasing (IUCN)

UK conservation status common (The Wildlife Trusts website)

Least concern, stable (IUCN)

UK conservation status green (RSPB website)

Least concern, stable (IUCN)

UK conservation status red (RSPB website)

Least concern, stable (IUCN)

UK conservation status green (RSPB website)

Least concern, stable (IUCN)

UK conservation status common (The Wildlife Trusts website)

Least concern, stable (IUCN)

UK conservation status red (RSPB website)

Least concern, decreasing (IUCN)

UK conservation status common (The Wildlife Trusts website)

UK conservation status introduced (RSPB website)

UK conservation status green (RSP website)

Least concern, increasing (IUCN)

UK conservation status amber (The Wildlife Trusts

website)

UK conservation status green (RSPB website)

UK conservation status common (The Wildlife Trusts website)

UK conservation status green (RSPB website)

UK conservation status amber (RSPB website)

UK conservation status red (RSPB website)

UK conservation status amber (RSPB website)

UK conservation status green (RSPB website)

UK conservation Status green (RSPB website)

UK conservation status amber (RSPB website)

UK conservation status green

UK conservation status common (The Wildlife Trusts website)

UK conservation status amber (RSPB website)

UK conservation status red (RSPB website)

UK conservation status green (RSPB website)

UK conservation status red (RSPB website)

UK conservation status amber (RSPB website)

UK conservation status green (RSPB website)

Butterfly Conservation Priority Medium (Butterfly

Conservation website)

UK conservation status amber

UK conservation status amber

UK conservation status Red
Roots of accounting for biodiversity

1857 
AAAJ 33,8

1858
Names of species as recorded by White (with updated names in brackets)

Extinction status of specific species and population trend

Tom-tit (blue tit, Cyanistes caeruleus)

Turtle-dove (Streptopelia turtur)

Viper, coluber berus (Vipera berus, European adder)

Wasps

Wheat-ear (wheatear, Oenanthe oenanthe)

White throat (Sylvia communis)

Grey wagtail (Motacilla cinerea)

White wagtail (Motacilla alba)

Wigeon (Anas Penelope)

Willow wren (willow warbler, Phylloscopus trochilus)

Windhover or "kestril" (kestrel, Falco

tinnunculus)
UK conservation status green (RSPB website)

UK conservation Status red (RSPB website)

Protected in the UK under the Wildlife and Countryside

Act, 1981. Priority Species under the UK Post-2010

Biodiversity Framework (Wildlife Trusts website)

UK conservation status green (The Wildlife Trusts website)

UK conservation status green (RSPB website)

UK conservation status red (RSPB website)

UK conservation status green (RSPB website)

UK conservation status amber (RSPB website)

UK conservation status amber

UK conservation status amber

the names he used in his Journals differ from the current species names. Where different names (the current name for a species) were found, we added these to White's original names in brackets. For example, the bat described by White as the vespertilio altivolans was identified through careful research as the European vespertilio murinus, a bat that occasionally visits the United Kingdom as a migrant and tends to be seen in the Southern coastal regions, where White lived. This bat is currently listed as "of least concern" by the IUCN [19]. Another salient example is White's recording of "black warty water-efts", known currently as "great crested newts". Fortunately, he provided the Latin name, triton cristatus, making identification easier. Where a species was not listed by the IUCN, we searched their status and have entered some information. For example, for the horsefly, the British media reported a dangerous (as they have a nasty bite) surge in their numbers during the heatwave which gripped the United Kingdom in July 2018. Where we found alternative information on specific species, we have identified the source. It is notable how substantially the names of species have altered since the 18th century. Despite careful study, there were some species we were unable to identify with any certainty. The plum weevil, for example, does not seem to be the one White identified as it is only present in North America. Further, there are 83 species of dung beetle (referred to by White as Scarabaeus solstitiales) such that it impossible to identify which ones he observed. There is, however, an ongoing dung beetle mapping exercise in the United Kingdom, given grave concerns over their decline. Where possible we have included information relating to conservation status of species in the United Kingdom as well as at IUCN/global level, to enable a comparison between White's British observations and the species populations in Britain at present. This seems important as many species deemed "of least concern" by the IUCN have a red or amber conservation status in the United Kingdom (e.g. the red-backed shrike).

Among the more harrowing findings from this created extinction account is a comparison of the status of mole crickets and field crickets, observed in abundance 250 years ago, with the current figures:

As mole-crickets often infest gardens by the sides of canals (White, 1788, p. 245).

Another species observed and recorded by White was the great bustard, with three sightings recorded in Table 1 . This bird became extinct soon after White's time, as the last individual was shot in 1832 . There have been recent attempts to reintroduce the species with around 
40 birds on Salisbury Plain [20]. The change in populations of house martins and other members of the swallow family is pertinent given White's research into their habits and life cycle. Between 1970 and 2014, there has been almost a 50\% fall in house martin numbers [21]. They currently have Amber conservation status in the United Kingdom. Changes in weather affect house martin populations [22]. Their populations are also affected by loss of habitat, as many barns where they traditionally nested have been converted to dwellings.

Another species used currently as a signifier of extinction threat among British wildlife is the hedgehog, a priority species for the UK's biodiversity action plan (see Table 2). Contrasting the species' current conservation status with White's narrative account of the hedgehog is striking - and sad:

Hedgehogs abound in my gardens and fields (White, 1788, p. 79).

Another illustration of how White's Journals can represent an extinction account arises from his comments on the abundance of grey partridge:

Partridges in vast plenty are bred in good seasons on the edge of this forest (White, 1788, p. 17).

As can be seen from Table 2, partridges are now classified under UK Conservation Status "Red" by the RSPB. Similarly, curlews were observed in abundance by White in 18th-century England, whereas Table 2 shows they are now listed as "Amber" in terms of UK Conservation Status.

I wonder that the stone-curlew, Charadrius oedicnemus, should be mentioned by the writers as a rare bird: it abounds in all the champaign parts of Hampshire and Sussex (White, 1788, pp. 45-46).

This comparative extinction account over a quarter of a millennium emphases further the usefulness of longitudinal accounting for biodiversity as an emancipatory tool that can be operationalised in order to prevent further extinctions and prevent further erosion of biodiversity [23]. Analysing his writings more broadly suggests White was an early extinction accountant, identifying not only the presence but also the absence of species (Scott, 2011). In places, he reported on the disappearance, or local extinction, of certain species, such as the red deer, oaks, turtles, worms, partridges. He talks of declining biodiversity within his own lifetime:

[T] am attended daily by a beautiful spaniel ... who amuses me in my walks by sometimes springing a pheasant or partridge, and seldom by flushing a woodcock, of late become with us a very rare bird (Holt-White, 2015, p. 245).

White documents the disappearance, or local extinction, of grouse and red deer, within his lifetime, but also with reference to local people he spoke to:

... there was a nobler species of game in this forest, now extinct, which I have heard old people say abounded much before shooting flying became so common, and that was the heath-cock, blackgame, or grouse. When I was a little boy I recollect one coming now and then to my father's table. The last pack remembered was killed about thirty-five years ago; and within these ten years one solitary greyhen was sprung by some beagles in beating for a hare (White, 1788, p. 17).

Nor does the loss of our black game prove the only gap in the Fauna Selborniensis; for another beautiful link in the chain of beings is wanting, I mean the red deer, which toward the beginning of this century amounted to about five hundred head, and made a stately appearance (White, 1788, p. 18).

Sadness in White's narrative is evident here and somewhat prophetic of the current human outpouring of grief at mass extinction we are witnessing some 250 years later. We also identify elements of White's Journal keeping that may be incorporated into an extinction accounting framework, so as to enhance and develop this template further. Table 3 provides 


\section{AAAJ 33,8}

\section{0}

2. Action-focussed reporting

3. Partnership reporting

Table 3.

A hybrid emancipatory extinction accounting framework including elements from White's Naturalist's Journal [28]
Purpose

Describe the extinction risk in the context of the organisation's business and the diverse reasons for wanting to address this risk
Explain the actions the company takes and plans to take to reduce extinction risk

Complement action-focussed reporting by explaining broader partnerships/ initiatives formed to combat/reverse extinction trends

Evaluation of extinction prevention initiatives against aims/targets to inform changes to actions and partnerships
Elements

Record a list of plant and animal species, identified as endangered by the IUCN

Red List, whose habitats are affected by the company's activities

Report where, geographically, the company's activities pose a threat to endangered plant and animal species, as identified by the IUCN Red List Report potential risks/impacts on these specific species arising from the company's operations (equivalent to the existing GRI principles to this point) Incorporate images (such as photographs, etchings, botanical drawings example) of vulnerable, threatened, endangered, critically endangered species which are affected by the company's operations and which the company has a duty of care to protect $a$ s well as aesthetic narrative elements Report full details (narrative as well as financial figures) relating to any fines or ongoing claims relating to endangered species legislation arising from the company's activities (e.g. CITES) as well as locational information relating to specific species within their habitats Report corporate expressions of moral, ethical, emotional, financial and reputational motivations for preserving species and preventing extinction (to respond to diverse needs and requirements of different stakeholders/ readers)

Report actions/initiatives taken by the company to avoid harm to, and to prevent extinction of, endangered plant and animal species including efforts to protect habitats and local ecosystems Report partnerships/engagement between wildlife/nature/conservation organisations and the company which aim to address corporate impacts on endangered species and report the outcome/impact of engagement/ partnerships on endangered species, habitats and ecosystems

Report assessment and reflection on outcome/impact of engagement/ partnerships and decisions taken about necessary changes to policy/initiatives going forward 


\begin{tabular}{ll}
\hline \multicolumn{1}{c}{ Element } & Purpose \\
\hline 5. Assessment & $\begin{array}{l}\text { Audit of affected species/populations/ } \\
\text { biomes }\end{array}$ \\
6. Reporting & $\begin{array}{l}\text { Provide an account of the progress made } \\
\text { to date on preventing or mitigating } \\
\text { extinction, planned future actions and } \\
\text { risk exposure }\end{array}$ \\
\end{tabular}

Elements

Report regular assessments (audit) of species populations in areas affected by corporate operations as well as assessments of habitat degradation or improvement

Report assessment of whether or not corporate initiatives/actions are assisting in prevention of species extinction and habitat protection

Report strategy for the future development and improvement of actions/initiatives: an iterative process Ensure that the whole process of "extinction accounting" is integrated into corporate strategy and is incorporated into the company's integrated report, the company's business plan, corporate strategy and risk management/internal control system not resigned to separate sustainability reports or websites Potential liabilities relating to future possible legal fines/claims relating to endangered species impacts Discussion of ways in which the company is working to prevent future liabilities related to harming endangered species

Provide pictorial representation of success in conservation - and of failure (i.e. species loss)

\section{Roots of accounting for biodiversity}

1861

an updated version of this extinction accounting framework, with Whitean accounting elements highlighted in bold.

This type of extinction account is consistent with the framework proposed by Atkins and Maroun (2018) and also draws on principles from the guidelines issued by the Global Reporting Initiative (GRI, 2016). This type of reporting may be considered by some as limited to individual organisations. As extinction of species is a cause for global concern, then company-specific reporting should be completed by accounting at the national and ecological level (Cuckston, 2017; Gaia and Jones, 2017; Russell et al., 2017). With this in mind, we modify the extinction accounting framework proposed by Atkins and Maroun (2018) for use at the macro level. For example, local or national governments, conservation bodies or NGOs may find this framework useful for constructing a "consolidated" extinction account, as presented in Table 4.

Consolidated extinction accounting uses ecosystems as the unit of account rather than specific firms. The aim is to provide a detailed account of the total biodiversity under review for the given region, country or biosphere. Drawing on Atkins and Maroun (2018), the GRI (2016) and White's Journals, this would include information on specific species as well as changes in their range and numbers. The accounts could be stratified according to extinction risk per the IUCN and should include measures of how this risk is changing over time (similar to the approach followed in Table 2). As the aim of the extinction account is emancipatory, users should be provided with an explanation of why these ecosystems are important, 
Table 4.

Consolidated extinction account

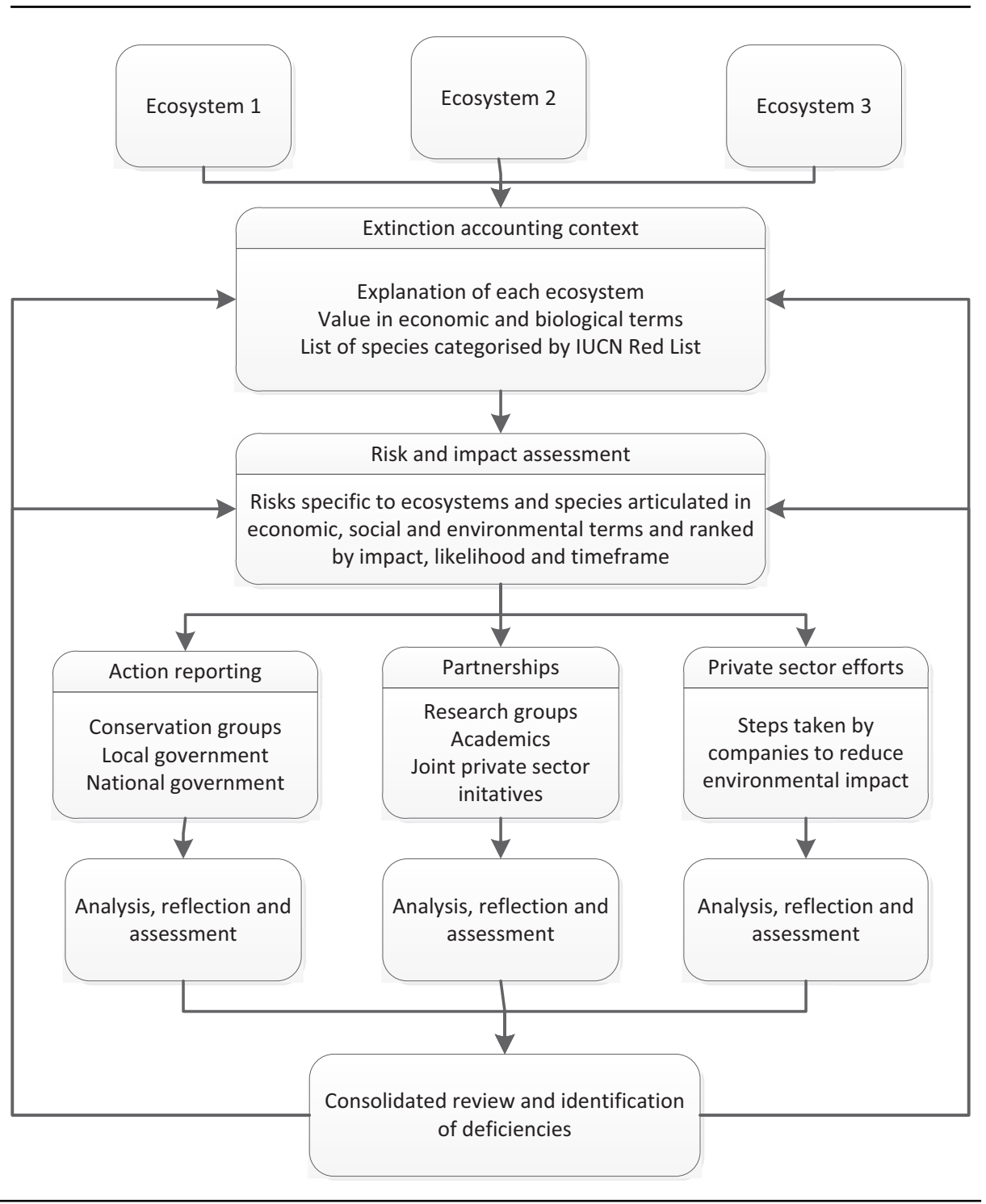

including economic considerations as well as the importance of flora and fauna at the social, cultural and, most importantly, biological level. In line with existing corporate governance practices, scientific details and the extinction context provide the basis for a comprehensive risk assessment. This includes: (1) an explanation of which ecosystems and species are most at risk of extinction, (2) the impact that this would have from a biological, social and economic perspective and (3) an indication of the likelihood of and time frame associated with each risk. This could be carried out at the national or regional level and would not be specific to a particular company or industry. A company account includes actions taken by the entity to 
mitigate the risk of extinction. Consolidated extinction accounting takes a broader approach to designing and explaining the response to identified risks. First is an explanation of the different entities (other than the private sector) tasked with risk management. Ideally, each risk would be mapped to the conservation groups, local governments and different parts of national government (as applicable) which are responsible for those risks. The policies and plans developed and actions taken by each responsible party would be articulated. As suggested by Atkins and Maroun (2018), partnerships formed with independent research groups, academics and the private sector would form part of the actions taken to combat extinction. Finally, the consolidated account should provide an aggregated assessment of what the private sector has done to reduce its environmental impact. Actions taken by individual companies contribute to the collective effort to prevent the loss of species and habit destruction. At the same time, the consolidated report provides stakeholders with an understanding of the extent to which the private sector, different levels of government and public benefit organisations are sharing the responsibility for conserving nature. Deficits in the accumulated response to extinction can also be discerned. At each level, an analysis of the steps taken to mitigate biodiversity loss would be provided. For the private sector, this would amount to review of companies' combined efforts, challenges encountered and material successes. To avoid a type of silo-logic, the consolidated account should map total activity to each risk showing which parties have responded to the different risks and whether or not the combined response has been adequate or successful. Deficiencies should be identified and used to inform changes to the risk assessment and/or response. Reflecting on White's accounting and a comparative extinction accounting over time has allowed us to propose tentative practical frameworks.

\section{Concluding discussion and suggestions for further research}

This paper contributes to the existing literature in a number of ways. The research explores the Naturalist's Journals of Gilbert White as an early illustration of accounting for biodiversity, thereby extending the literature on biodiversity accounting into a historic context. Further, the paper seeks to extend the form of biodiversity accounting from the corporate, public sector sphere into the personal, individual sphere whereby interested parties and naturalists provide accounts of species and biodiversity through the medium of a journal. We are therefore answering calls from the accounting history literature to explore environmental and sustainability accounting from a historical perspective as well as to broaden the forms of account researched. Our research also extends the existing literature on extinction accounting by providing a longitudinal extinction account over a 250 -years period, by comparing the biodiversity account derived from White's Naturalist's Journals with an account of the current state of UK (and in some cases global) species he recorded, according to extinction threat. Although there are emerging illustrations of extinction accounting for a variety of species in the literature, there is none that adopts such a longitudinal historical perspective. Here we are seeking to gain a feeling for biodiversity and species losses since the 1770s. From a more interdisciplinary perspective, this paper may be seen as a means of opening up academic debate around chaos ecology, since White's Journals may be interpreted as early examples of this somewhat apocalyptic genre of writing and thought, but also writing which identifies the devastating impact our species is having on nature, on flora and fauna and on biodiversity. The potential impact of comparing White's Journals to the current state of nature has been recognised in literary analyses, and using extinction accounting as a frame is an effective means of operationalising such comparison:

White's daily nature observations constitute a mode of resistance that we can recognize as ideologically significant both to his contemporary period of landscape and agricultural change and to our own moment of ecological crisis (Williams, 2017, p. 436). 
AAAJ 33,8

1864
Lawton (1999) highlighted the striking difference between White's Selborne and the same region at present, mentioning species he recorded as abundant being now absent or dwindling. We can only hope that this 250 -years-old extinction account brings to life White's diligent biodiversity reporting practices in the 21st century, transforming them into a potentially powerful emancipatory mechanism for raising societal awareness around the need for action to preserve species from extinction. It is also worthwhile reflecting on whether White's Naturalist's Journals represent an appropriate model of the types of data that we should be collecting at present: perhaps living in a high octane, "big data" world is contributing to extinction and biodiversity loss, such that the practice of localised biodiversity diaries, collected at a different rhythm and pace, is exactly what the world needs [24]. Indeed, there may be benefit in theorising accounting for biodiversity and extinction using philosophical and theoretical approaches that explore further the relationship between nature and man/woman and how this currently adversarial relationship may be enhanced in the light of ecological crisis. For instance, the varied works of the Scottish poet Kenneth White could offer a framing, as his core concept of "geopoetics" [25], originating from his doctoral thesis on the subject of the "Intellectual Nomad", focusses on the state of human beings in the universe and their relationship with planet Earth (Bell, 2009) [26].

We also hope that this paper can provide a springboard, a motivation, for researchers to explore the historical roots of ecological accounting and auditing, from multiple perspectives including different forms of accounting for biodiversity and extinction, such as nature diaries and other written media, even artworks or letters. For example, Henry David Thoreau's (Thoreau, 1856-1857) extensive journal-keeping provides an ideal basis for further research along these lines, as his detailed accounts, totalling more than $2 \mathrm{~m}$ words, describe nature and species he saw in sensitive and artistic terms, such as ".... [T] he banks by retired roadsides are covered with asters, hazels, brakes, and huckleberry bushes, emitting a dry, ripe scent” (p. 450) [27]. Thoreau lived in Massachusetts, practising an ethical form of life and inspiring people through his writings that raise issues around society and the environment. His species data could be compared to the current state of biodiversity in Massachusetts at present to create a US-based extinction account. Further, the artistic accounts included in nature diaries could be analysed as forms of biodiversity account, such as the botanical drawings and paintings included in the Country Diary of an Edwardian Lady (Holden, 1980). Indeed, it would be interesting to explore female nature diarists, as women are represented in this literary genre. For example, Dorothy Wordsworth and Beatrix Potter included detailed nature notes in their journals. Researchers could also potentially explore similar types of biodiversity and extinction accounting in different countries, languages and cultures, extending this work from a purely UK-focussed context. Analysing White's brother's journals recording species in Gibraltar around a quarter of a millennium ago, could engender some useful insights into species change in Southern Europe over this period. This is a potentially fruitful area of research, as understanding historical contexts and frameworks can inform the development of current and future reporting and accounting forms, media and communicative methods.

\section{Notes}

1. For example, the household accounts of Octavia Hill were analysed in a biographical manner exploring her historical context and surroundings (Walker, 2006).

2. See Johnson (eds) (1970).

3. Arthropods are invertebrates including insects which have external skeletons (Lister and Garcia, 2018).

4. The crucial role of bees and the need for financial and accounting systems to incorporate bee loss as a substantial risk have been acknowledged in the accounting literature (Atkins and Atkins, 2016). 
5. The publication of the report instigated debate and contributed to the enactment of the River Pollution Act.

6. See White (1877) and Emden (1948).

7. Barrington was the Recorder of Bristol and a dilettante in science and letters (Clegg, 1975).

8. The Journal includes the inscription by White, "The gift of the Honourable Mr. Barrington, the inventor" (Clegg, 1975, p. xiii).

9. Barrington mentioned these potential "users" of the accounts in the preface to his Journal.

10. These were the Journals for 1774 and 1775.

11. See Foster (1988) for a detailed discussion of this "auditing" process.

12. One example was Barrington's question about who provided the account of a spoonbill that had been shot, an event recorded in the Journal.

13. Not to mention the time that would have to be invested in studying the original manuscripts, which we feel would not materially alter our tables of accounts.

14. For the most part the editor stated he excluded White's daily record of temperature, air pressure and other weather-related details

15. Indeed, Foster (1988) comments on how White's recording improved over time.

16. As, for example, may be seen in William Gilpin's travel diaries which describe nature and landscape in 18th-century Britain, discussed in Atkins and Atkins (2018).

17. Interestingly, Darwin did not acknowledge White in his work on worms, but researchers have suggested that this may have been a purposeful oversight as White was not the only predecessor he failed to mention including his own grandfather (see Cadée, 2003).

18. It was only possible to search for species where he was specific, rather than where he recorded "ants" or "aphids". We did not include those species that are garden plants rather than natural fauna nor did we include species where the specific type was not recorded.

19. The "least concern" category is used to outline population status of species that are not seen as threatened with extinction at present and with the data available, although many of these have declining populations which does indicate a potential issue in coming years. Species are only included on the IUCN website if research has been conducted into their population status and extinction threat.

20. This information and more is available here: https://www.rspb.org.uk/our-work/conservation/ projects/reintroducing-the-great-bustard-to-southern-england.

21. This information comes from the following website: https://www.rspb.org.uk/birds-and-wildlife/ wildlife-guides/bird-a-z/house-martin/population-trends/.

22. They need wet mud to build their nests. They also require warm weather to ensure insects for food. Dry weather due to higher temperatures (linked to global warming) coupled with insect decline for a wide variety of reasons is likely to be reducing their numbers.

23. Earlier literature highlighted the emancipatory potential of extinction accounting by organisations, or other bodies, in order to use the dynamic status of species populations as a call for action and transformational change (Maroun and Atkins, 2018; Atkins and Atkins, 2019).

24. We are grateful to one of our anonymous reviewers for making this point: it ushers researchers to explore ways of changing our relationship with nature as a means perhaps of healing existing and expanding wounds.

25. See, for example, White $(1992,2003)$ for expositions of the concept of geopoetics.

26. We are again grateful to one of our anonymous reviewers for drawing our attention to Kenneth White's work, which seems to offer a potential way forward for further research into humans, nature, ecology and extinction, from an alternative accounts perspective. 
AAAJ 33,8

27. We thank one of our anonymous reviewers for pointing us towards Thoreau's work.

28. This framework has been adapted from the framework published in Atkins and Maroun (2018).

\section{References}

Adams, R. (1985), A Nature Diary, Penguin Books Ltd, Middlesex.

Allen, D.E. (1976), The Naturalist in Britain: A Social History, Allen Lane, London.

Atkins, J.F. and Atkins, B.C. (Eds) (2016), The Business of Bees, An Integrated Approach to Bee Decline, June, Greenleaf Publishers, Saltaire.

Atkins, J.F. and Atkins, B.C. (2018), "William Gilpin's narrative accounts of nature, landscape and industrial pollution: from grotesque to Picturesque?", Plenary Paper Presented at the Meditari Accountancy Conference in South Africa, June.

Atkins, J.F. and Atkins, B.C. (2019), Around the World in 80 Species: Exploring the Business of Extinction, Routledge, Abingdon.

Atkins, J.F. and Maroun, W. (2018), "Integrated extinction accounting and accountability: building an ark", Accounting, Auditing and Accountability Journal, Vol. 31 No. 3, pp. 1-41.

Atkins, J. and Thomson, I. (2014), "Accounting for nature in 19th century Britain: William Morris and the defence of the fairness of the Earth", in Jones (Eds), Accounting for Biodiversity, Routledge.

Atkins, J., Atkins, B., Thomson, I. and Maroun, W. (2015), “'Good' news from nowhere: imagining utopian sustainable accounting", Accounting, Auditing and Accountability Journal, Vol. 28 No. 5 , pp. 651-670.

Atkins, J.F., Maroun, W., Atkins, B.C. and Barone, E. (2018), "From the big five to the big four? exploring extinction accounting for the rhinoceros?", Accounting, Auditing and Accountability Journal, Vol. 31 No. 2, pp. 1-31.

Barrington, D. (1767), The Naturalist's Journal, British Library, B.L. Add MS 31846-31851, London.

Bell, I. (2009), "A long walk with Kenneth White", Scottish Review of Books, 28th October, available at: https://www.scottishreviewofbooks.org/2009/10/a-long-walk-with-kenneth-white/.

Bellanca, M.E. (2007), Daybooks of Discovery: Nature Diaries in Britain 1770-1870, University of Virginia Press, Virginia, VA.

Buchling, M. and Maroun, W., (2019), "Extinction accounting by the public sector: South African National Parks", in Atkins, J.F. and Atkins, B.C. (Eds), Around the World in 80 Species: Exploring the Business of Extinction, Chapter 11, Routledge, Abingdon, pp. 201-218.

Burchell, S., Clubb, C., Hopwood, A., Hughes, J. and Nahapiet, J. (1980), "The roles of accounting in organizations and society", Accounting, Organizations and Society, Vol. 5 No. 1, pp. 5-27.

Cadée, G.C. (2003), “Gilbert white and Darwin’s worms”, Ichnos, Vol. 10, pp. 47-49.

Carnegie, G.D. and Napier, C.J. (2017), "Historiography in accounting research", in Hoque, Z., Parker, L.D., Covaleski, M. and Haynes, K. (Eds), The Routledge Companion to Qualitative Accounting Research Methods, Chapter 5, Routledge, Abingdon.

Carnegie, G.D. and Napier, C.J. (1996), "Critical and interpretive histories: insights into accounting's present and future through its past", Accounting, Auditing and Accountability Journal, Vol. 9 No. 3, pp. 7-39.

Clegg, J. (1975), Gilbert White: Garden Kalendar 1751-1771, The Scolar Press Limited, London.

Cuckston, T. (2017), "Ecology-centred accounting for biodiversity in the production of a blanket bog", Accounting, Auditing and Accountability Journal, Vol. 30 No. 7, pp. 1537-1567.

Cuckston, T. (2018), "Making extinction calculable", Accounting, Auditing and Accountability Journal, Vol. 31 No. 3, pp. 849-874. 
Egerton, F.N. (2007), "A history of the ecological sciences, Part 26: Gilbert white, naturalist Extraordinaire", Bulletin of the Ecological Society of America, Vol. 88 No. 4, Published by Wiley on behalf of the Ecological Society of America, pp. 385-398.

Emden, C.S. (1948), Oriel Papers, Clarendon Press, Oxford.

Ezzamel, M. and Hoskin, K. (2002), "Retheorising accounting, writing and money with evidence from Mesopotamia and Ancient Egypt", Critical Perspectives on Accounting, Vol. 13, pp. 333-367.

Foster, P.G.M. (1988), Gilbert White and his Records: A Scientific Biography, Christopher Helm (Publishers), Bromley, Kent.

Fussell, D. (1990), "The greening eye: Gilbert white, the Picturesque and natural history", Critical Survey, Science and the Nineteenth Century, Vol. 2 No. 1, pp. 14-20.

Gaia, S. and Jones, M.J. (2017), "UK local councils reporting of biodiversity values: a stakeholder perspective", Accounting, Auditing and Accountability Journal, Vol. 30 No. 7, pp. 1614-1638.

Gallhofer, S. and Haslam, J. (2003), Accounting and Emancipation: Some Critical Interventions, Routledge, London.

Gallhofer, S., Haslam, J. and Yonekura, A. (2015), "Accounting as differentiated universal for emancipatory praxis: accounting delineation and mobilisation for emancipation(s) recognising democracy and difference", Accounting, Auditing and Accountability Journal, Vol. 28 No. 5, pp. 846-874.

Gray, R. (2010), "Is accounting for sustainability actually accounting for sustainability... and how would we know? an exploration of narratives of organisations and the planet", Accounting, Organizations and Society, Vol. 35 No. 1, pp. 47-62.

Gray, R. and Milne, M.J. (2018), "Perhaps the Dodo should have accounted for human beings? accounts of humanity and (its) extinction", Accounting, Auditing and Accountability Journal, Vol. 31 No. 3, pp. 826-848.

GRI (2016), “Consolidated set of GRI sustainability reporting standards (2016)", available at: https:// www.globalreporting.org/standards/gri-standards-download-center/?g=ae2e23b8-4958-455c-a9 df-ac372d6ed9a8, https://www.globalreporting.org/reporting/g4/Pages/default.aspx (accessed 10 February 2017).

Guthrie, J. and Parker, L.D. (1989), "Corporate social reporting: a Rebuttal of legitimacy theory", Accounting and Business Research, Vol. 19 No. 76, pp. 343-352.

Holden, E. (1980), The Country Diary of an Edwardian Lady, Michael Joseph/Webb and Bower, London.

Holt-White, R. (2015 first publised 1901), Life and Letters of Gilbert White of Selborne, Vol. II, Cambridge University Press, Cambridge.

Hopwood, A.G. (1987), "The archaeology of accounting systems", Accounting, Organizations and Society, Vol. 12 No. 3, pp. 207-234.

Hoskin, K.W. and Macve, R.H. (1988), "The genesis of accountability: the west point connections", Accounting, Organizations and Society, Vol. 13 No. 1, pp. 37-73.

IIRC (2013), "The international framework: integrated reporting”, available at: http://www.theiirc.org/ wp-content/uploads/2013/12/13-12-08-THE-INTERNATIONAL-IR-FRAMEWORK-2-1.pdf (accessed 1 October 2013).

Intergovernmental Panel on Climate Change (2013), Climate Change 2013: The Physical Science Basis, available at: http://www.ipcc.ch/report/ar5/wg1/ (accessed 1 June 2015).

Johnson, W. (Ed.) (1970), Gilbert White's Journals, Routledge and Kegan Paul, London, First published 1931.

Jonäll, K. and Sabelfeld, S. (2019), "Accounting for survival of polar bears: an arctic icon on thin ice”, in Atkins, J.F. and Atkins, B.C. (Eds), Around the World in 80 Species: Exploring the Business of Extinction, Chapter 18, Routledge, Abingdon, pp. 337-356.
Roots of
accounting for
biodiversity

1867 
Jones, M.J. (1996), “Accounting for biodiversity: a pilot study”, The British Accounting Review, Vol. 28 No. 4, pp. 281-303.

Jones, M.J. (2003), "Accounting for biodiversity: operationalising environmental accounting", Accounting, Auditing and Accountability Journal, Vol. 16 No. 5, pp. 762-789.

Jones, M.J. and Solomon, J.F. (2013), "Problematising accounting for biodiversity", Accounting, Auditing and Accountability Journal, Vol. 26 No. 5, pp. 668-687.

Kilvert, R.F. (1977), Kilvert's Diary 1870-1879, Selected and, W. Plomer, Penguin, London.

Lanka, S.V. (2019), "An ecological auto-ethnography of a monarch butterfly", in Atkins, J.F. and Atkins, B.C. (Eds), Around the World in 80 Species: Exploring the Business of Extinction, chapter 17, Routledge, Abingdon, pp. 324-334.

Lawton, J. (1999), “Time to reflect: Gilbert white and environmental change”, Oikos, Vol. 87 No. 3, pp. 476-478.

Lewis, N., Parker, L. and Sutcliffe, P. (1984), "Financial reporting to employees: the pattern of development 1919 to 1979", Accounting, Organizations and Society, Vol. 19 No. 314, pp. 275-290.

Lister, B.C. and Garcia, A. (2018), "Climate-Driven declines in arthropod abundance restructure a rainforest food web", Proceedings of the National Academy of Sciences of the United States of America, Vol. 115 No. 44, pp. 1-10, October, doi: 10.1073/pnas.1722477115.

Looker, S.J. (Ed.). (1941), The Nature Diaries and Note-Books of Richard Jefferies with an Essay, "A Tangle of Autumn”, The Grey Walls Press, Billericay, Essex.

Mabey, R. (2011), "Introduction", in Jeffries, R. (Ed.), Wild Life in a Southern County, (2011), Little Toller Books, Stanbridge, Dorset, pp. 7-13.

Macve, R.H. (2015), "Fair value vs conservatism? Aspects of the history of accounting, auditing, business and finance from ancient Mesopotamia to modern China", The British Accounting Review, Vol. 47 No. 2, pp. 124-141.

Maltby, J. (2004), "Hadfields Ltd: its annual general meetings 1903-1939 and their relevance for contemporary corporate social reporting”, British Accounting Review, Vol. 36, pp. 415-439.

Maltessich, R. (1998), "Recent insights into Mesopotamian accounting of the 3rd millennium BC successor to token accounting", Accounting History Journal, Vol. 25 No. 1, pp. 1-27.

Maroun, W. and Atkins, J.F. (2018), "The emancipatory potential of extinction accounting: exploring current practice in integrated reports", Accounting Forum, Vol. 42, pp. 102-118.

Martin, E.A. (1934), A Bibliography of Gilbert White, the Naturalist and Antiquarian of Selborne, with a Biography and a Descriptive Account of the Village of Selborne, Halton, London.

Massingham, H.J. (1920), “Gilbert White”, The Athenaeum, August 27th, pp. 263-265.

Menely, T. (2004), “Traveling in place: Gilbert White's cosmopolitan parochialism”, Eighteenth-Century Life, Vol. 28 No. 3, pp. 46-65.

Mullett, C.F. (1969), "Multum in Paravo: Gilbert white of Selborne", Journal of the History of Biology, Vol. 2 No. 2, Autumn, pp. 363-389.

Napier, C.J. (2002), "The historian as auditor: facts, judgements and evidence”, Accounting Historians Journal, Vol. 29 No. 2, December, pp. 131-155.

Napier, C.J. (2006), Researching accounting Changes in a Period of Change: Theories and Methods of Accounting History, $\mathrm{PhD}$ thesis, University of Southampton.

Parker, L.D. (2015), “Accounting historiography: looking back to the future”, Meditari Accountancy Research, Vol. 23, pp. 142-157.

Peterson, L.H. (2010), "Writing nature at the fin de siècle: Grant Allen, Alice Meynell, and the split legacy of Gilbert White", Victorian Review, Vol. 36 No. 2, Fall, pp. 80-91.

Rimmel, G. and Jonäll, K. (2013), "Biodiversity reporting in Sweden: corporate disclosure and preparers' views", Accounting, Auditing and Accountability Journal, Vol. 26 No. 5, pp. 746-778. 
Rimmel, G. (2019), "Extinction accounting in European zoos: reporting practice of conservation programmes to protect animals from extinction", in Atkins, J.F. and Atkins, B.C. (Eds), Around the World in 80 Species: Exploring the Business of Extinction, chapter 11, Routledge, Abingdon, pp. 221-235.

Ruskin, J. (1884), The Storm Cloud of the Nineteenth Century, Two Lectures Delivered at the London Institution, 4th and 11th February, John Wiley and Sons, New York, NY.

Russell, S., Milne, M.J. and Dey, C. (2017), "Accounts of nature and the nature of accounts: critical reflections on environmental accounting and propositions for ecologically informed accounting", Accounting, Auditing and Accountability Journal, Vol. 30 No. 7, pp. 1426-1458.

Schmandt-Basserat, D.C. (1988), "From accounting to written language: the role of abstract counting in the invention of writing", in B.A.R. and D.L. (Eds), Chapter 5 The Social Construction of Written Communication, Ablex Publishing Company, New Jersey, NJ, pp. 119-146.

Scott, H.S. (2011), “Apocalypse narrative, chaotic system: Gilbert White's Natural History of Selbourne and modern ecology", Romanticism and Victorianism on the New, March 8th, Vol. 56 November, Online Publication, available at: https://www.erudit.org/en/journals/ravon/2009-n56-ravon1503 285/1001095ar/.

Sibanda, M. and Mulama, M. (2019), "Business contributions to extinction risk mitigation for black rhinos in Laikipia, Kenya", in Atkins, J.F. and Atkins, B.C. (Eds), Around the World in 80 Species: Exploring the Business of Extinction, Chapter 10, Routledge, Abingdon, pp. 192-200.

Solomon, A. and Clappison, M. (2019), "Accounting for captive belugas: a whale of a business", in Atkins, J.F. and Atkins, B.C. (Eds), Around the World in 80 Species: Exploring the Business of Extinction, Chapter 16, Routledge, Abingdon, pp. 289-323.

Solomon, J.F. and Thomson, I. (2009), "Satanic mills? an illustration of victorian external environmental accounting", Accounting Forum.

Sullivan, S. and Hannis, M. (2017), "Mathematics maybe, but not money': on balance sheets, numbers and nature in ecological accounting”, Accounting, Auditing and Accountability Journal, Vol. 30 No. 7, pp. 1459-1480.

Thomson, I., Dey, C. and Russell, S. (2015), “Activism, arenas and accounts in conflicts over tobacco control”, Accounting, Auditing and Accountability Journal, Vol. 28 No. 5, pp. 809-845.

Thoreau, H.D. (1856-1857), "Gleanings - or what time has not Reaped of my journal", Journal IX, August 16, 1856 - August 7, 1857.

Tregidga, H., Milne, M. and Kearins, K. (2014), “(Re)presenting 'sustainable organizations", Accounting, Organizations and Society, Vol. 39 No. 6, pp. 477-494.

Unerman, J. (2003), "Enhancing organizational global hegemony with narrative accounting disclosures: an early example", Accounting Forum, Vol. 27 No. 4, pp. 425-449.

Van Liempd, D. and Busch, J. (2013), "Biodiversity reporting in Denmark", Accounting, Auditing and Accountability Journal, Vol. 26 No. 5, pp. 833-872.

Walker, S.P. (2006), "Philanthropic women and accounting. Octavia Hill and the exercise of "quiet power and sympathy”, Accounting, Business and Financial History, Vol. 16 No. 2, pp. 163-194.

Watts, R.L. and Zimmerman, J.L. (1983), "Agency problems, auditing, and the theory of the firm: some evidence", Journal of Law and Economics, Vol. 26 No. 3, pp. 613-633.

Weir, K. (2018), "The purposes, promises and compromises of extinction accounting in the UK public sector", Accounting, Auditing and Accountability Journal, Vol. 31 No. 3, pp. 875-899.

White, G. (1774), "An Account of the House Martin, or Martlet”, The Weekly Miscellany, Inserted in the 64th Volume of the Philosophical Transactions.

White, G. (1788), The Natural History and Antiquities of Selborne, in Jardine, S.W. (Ed.), Published in 1880, by George Routledge and Sons Limited, London.

White, G. (1877), The Natural History and Antiquities of Selborne, in Bell, T. (Ed.), Van Voorst, London, Vol. 2. 
AAAJ 33,8

White, K. (1992), “Elements of geopoetics”, Edinburgh Review, Vol. 88, pp. 163-68.

White, K. (2003), Open World: The Collected Poems 1960-2000, Polygon, Edinburgh.

Williams, R. (2017), “Gilbert White's eighteenth-century nature journals as 'everyday' ecology”, Interdisciplinary Studies in Literature and Environment, Vol. 24 No. 3, pp. 432-456.

WWF (2018), Living Planet Report - 2018: Aiming Higher, in Grooten, M. and Almond, R.E.A. (Eds), WWF, Gland.

Zhao, L. and Atkins, J.F. (2019), "Panda accounting and accountability: preventing giant panda extinction in China", in Atkins, J.F. and Atkins, B.C. (Eds), Around the World in 80 Species: Exploring the Business of Extinction, chapter 19, Routledge, Abingdon, pp. 359-388.

\section{Further reading}

Dadswell, T. (2006), The Selbourne Pioneer: Gilbert White as Naturalist and Scientist, a Reexamination, Centaur Press, London.

Emden, C.S. (1956), Gilbert White in his Village, Clarendon Press, Oxford.

Johnson, W. (1928), Gilbert White: Pioneer, Poet and Stylist, John Murray, London.

Mabey, R. (2006), Gilbert White: A Biography of the Author of the Natural History of Selborne, Profile Books, London, First published in 1986 by Century Hutchinson Limited.

Rye, A. (1970), Gilbert White and his Selbourne, William Kimber, London.

Solomon, J.F. (2009), The Stormcloud of the Nineteenth Century: An Early Illustration of Pollution Accounting, Working Paper, King's College London.

White, G. (1994), The Natural History and Antiquities of Selbourne, Originally Published in 1788 by Benjamin White and Son, This edition published by, The Folio Society, London.

\section{Corresponding author}

Jill Atkins can be contacted at: j.f.atkins@sheffield.ac.uk

For instructions on how to order reprints of this article, please visit our website:

www.emeraldgrouppublishing.com/licensing/reprints.htm

Or contact us for further details: permissions@emeraldinsight.com 